\title{
Hydrogeology, Chemical and Microbial Activity Measurement Through Deep Permafrost
}

\author{
by Randy L. Stotler ${ }^{1,2}$, Shaun K. Frape ${ }^{3}$, Barry M. Freifeld ${ }^{4}$, Brian Holden ${ }^{3}$, Tullis C. \\ Onstott $^{5}$, Timo Ruskeeniemi ${ }^{6}$, and Eric Chan ${ }^{5,7}$ \\ ${ }^{1}$ Corresponding author: Department of Earth Sciences, University of Waterloo, Waterloo, Ontario, Canada; \\ 1-785-864-2096, fax 1-785-864-5317; stotler@kgs.ku.edu \\ ${ }^{2}$ Currently at Kansas Geological Survey, University of Kansas, Lawrence, KS 66047. \\ ${ }^{3}$ Department of Earth Sciences, University of Waterloo, Waterloo, Ontario, Canada N2L 3G1. \\ ${ }^{4}$ Earth Sciences Division, Lawrence Berkeley National Laboratory, Berkeley, CA 94720. (Work performed \\ by B.M.F. is partially supported by the U.S. Department of Energy and LBNL under Contract No. DE- \\ AC02-05CH11231.) \\ ${ }^{5}$ Department of Geosciences, Princeton University, Princeton, NJ 08544 \\ ${ }^{6}$ Geological Survey of Finland, Espoo, Finland, FI-02151 \\ ${ }^{7}$ Currently at Department of Oceanography, Texas A\&M, University, College Station, TX 77843
}

\begin{abstract}
Little is known about hydrogeochemical conditions beneath thick permafrost, particularly in fractured crystalline rock, due to difficulty in accessing this environment. The purpose of this investigation was to develop methods to obtain physical, chemical, and microbial information about the subpermafrost environment from a surface-drilled borehole. Using a U-tube, gas and water samples were collected, along with temperature, pressure, and hydraulic conductivity measurements, $420 \mathrm{~m}$ below ground surface, within a $535 \mathrm{~m}$ long, angled borehole at High Lake, Nunavut, Canada, in an area with $460 \mathrm{~m}$ thick permafrost. Piezometric head was well above the base of the permafrost, near land surface. Initial water samples were contaminated with drill fluid, with later samples $<40 \%$ drill fluid. The salinity of the non-drill fluid component was $<20,000 \mathrm{mg} / \mathrm{L}$, had a $\mathrm{Ca} / \mathrm{Na}$ ratio above 1 , with $\delta^{18} \mathrm{O}$ values $\sim 5 \%$ o lower than the local surface water. The fluid isotopic composition was affected by the permafrost-formation process. Nonbacteriogenic $\mathrm{CH}_{4}$ was present and the sample location was within methane hydrate stability field. Sampling lines froze before uncontaminated samples from the subpermafrost environment could be obtained, yet the available time to obtain water samples was extended compared to previous studies. Temperature measurements collected from a distributed temperature sensor indicated that this issue can be overcome easily in the future. The lack of methanogenic $\mathrm{CH}_{4}$ is consistent with the high sulfate concentrations observed in cores. The combined surface-drilled borehole/U-tube approach can provide a large amount of physical, chemical, and microbial data from the subpermafrost environment with few, controllable, sources of contamination.
\end{abstract}

\section{Introduction}

Information about hydrogeochemistry of the deep permafrost and subpermafrost is currently sought by a number of disparate research interests, including the search for "extreme life," safe disposal of nuclear waste, climate change modeling, and site assessment for new mining developments (e.g., Freifeld et al. 2008a; Gartner Lee Ltd. 2006a; Onstott et al. 2009; Pfiffner et al. 2008; Stotler et al. 2009). Permafrost is commonly misunderstood to be entirely frozen, with minimal possibility for through- flow due to the low-permeable ice. However, permafrost is defined by the $0 \circ \mathrm{C}$ isotherm, and does not actually denote the presence or absence of ice, as the freezing point of water is dependent on factors beyond temperature, such as pressure and salinity (van Everdingen 1976).

The only information about the deep subpermafrost environment has been obtained from oil and gas drilling 
deep in sediments, with relatively few fractured rock investigations (e.g., Alexeev and Alexeeva 2002, 2003; Dallimore et al. 1999; Dallimore and Collett 2005). A majority of permafrost literature is concerned with surficial processes within the active layer, although recent research into permafrost degradation due to climate change is also available (Jorgenson et al. 2006; Vidstrand 2008). In a translated review of Russian literature, Tolstikhin and Tolstikhin (1974) suggest that small lags observed between surface water level fluctuations and piezometric levels indicate that open taliks can provide a hydraulic link through relatively thick permafrost. In the sedimentary Siberian Platform, several geochemical processes are known to affect fluid geochemistry, including evaporation, halite dissolution, and concentration due to ion exclusion during freezing (Alexeev and Alexeeva 2002, 2003; Shouakar-Stash et al. 2007). In the absence of open taliks and during closed system freezing, solutes concentrate in residual subpermafrost water as ice formation removes dilute fluid. The resulting fluids could have salinities and chemistries that are high enough to inhibit fluid freezing at subzero temperatures, especially Ca-rich fluids. This leads to the formation of cryopegs and unfrozen high salinity fluid pockets within the permafrost (van Everdingen 1976). If a subzero cryopeg extends through the permafrost, it is termed a "hydrochemical talik." This is different from "hydrothermal taliks," that are typically found beneath large watercourses where mean annual bottom temperatures remain above the freezing point (i.e., the watercourse does not freeze down to the bottom) (van Everdingen 1976; Mackay 1992; Burn 2002). Another important feature of permafrost when considering groundwater flow and chemistry are gas hydrates, in particular methane hydrate. Methane hydrates form in certain low temperature and high pressure conditions, in areas with high gas concentrations (Kvenvolden and Lorenson 2001). These crystalline structures of stabilized water and gas affect fluid geochemistry and reduce hydraulic conductivity (Trofimuk et al. 1974; Hesse and Harrison 1981; Kleinberg et al. 2003). All these features make the geochemistry of the basal permafrost and immediate subpermafrost environment sensitive to the hydrological characteristics, and vice versa. This is especially true for low permeability, fractured crystalline rock, for which little data exist.

To address the dearth of information on crystalline subpermafrost hydrology, an investigation into the composition of permafrost and subpermafrost water was conducted underground at the crystalline Lupin $\mathrm{Au}$ Mine in Nunavut, Canada (Ruskeeniemi et al. 2002, 2004; Stotler 2008; Stotler et al. 2009; 2010b; Onstott et al. 2009). Water and gases were collected from sealed exploration boreholes, mine seeps, and research boreholes throughout the permafrost and subpermafrost (Stotler et al. 2009). Several important research objectives were not answered at the Lupin Au Mine, partially due to the effects associated with 20 years of mining prior to research activities. For instance, mixing between resident groundwater and brines used for drilling precluded thorough evaluation of the importance of the freezing process during permafrost formation as a solute concentration mechanism over large scales in crystalline rocks (Stotler et al. 2009). Low hydraulic pressures, attributed to mine dewatering, resulted in an unsaturated zone at the base of the permafrost, and hydraulic pressures beneath undisturbed permafrost remained unknown. $\mathrm{SO}_{4}$-reducing bacteria dominated the sub-permafrost microbial ecosystem and $\mathrm{SO}_{4}$ was the dominant electron acceptor despite its low, $\sim 100 \mu \mathrm{M}$, concentration (Onstott et al. 2009). The rates of microbial $\mathrm{SO}_{4}$ reduction were not measured for the subpermafrost water at the Lupin Au Mine before the mine was closed, nor was it possible to determine how these rates compared to those of the overlying permafrost.

Data from an additional permafrost location were required to corroborate conclusions obtained and hypotheses formed at the Lupin Au Mine. However, additional sites were not available for underground-based investigation, and the potential to investigate an uncontaminated site was desired. Thus, the potential for sampling the deep-permafrost and subpermafrost environment from surface-drilled boreholes was explored. Past mine feasibility and environmental assessment studies conducted throughout the Arctic have used surface-drilled boreholes to characterize physical hydrogeological conditions (Cumberland Resources 2005; Gartner Lee Ltd. 2006a,b; SRK Consulting 2005). However, these boreholes were drilled with brine to counteract the subzero drilling conditions, and little effort was made to obtain uncontaminated geochemical samples. Thus, the true chemical nature of fluids in subpermafrost settings could not be determined from surface-drilled boreholes. Borehole ice formation also precluded the collection of more than one set of fluid samples from a given borehole due to post-drilling ice formation.

The purpose of this investigation was to develop methods to obtain high quality physical, chemical, and microbiological information about the subpermafrost environment from a borehole drilled from the surface through the permafrost. This paper focuses on challenges encountered and possible solutions to improve collection of data from beneath permafrost, with the aim of aiding future studies in this relatively unexplored setting. Results of data collection from the deep permafrost are presented to demonstrate the usefulness of the methodology, the range of information that can be collected from a single borehole, to describe the effectiveness of this technique, and to compare results with studies in excavated caverns. The new location also allows the opportunity to test hypotheses drawn from the Lupin Au Mine regarding site-specific vs. permafrost formation related trends and processes.

\section{Site Description}

The study site was located at the High Lake $\mathrm{Zn}-\mathrm{Cu}$ prospect, in the Nunavut Territory, Canada $\left(67^{\circ} 22^{\prime} 47^{\prime \prime} \mathrm{N}\right.$, $\left.110^{\circ} 50^{\prime} 37^{\prime \prime} \mathrm{W}\right)$ about $550 \mathrm{~km}$ north-northeast of Yellowknife, Northwest Territories, $40 \mathrm{~km}$ south of Coronation Gulf, and $169 \mathrm{~km}$ north of the Lupin Au Mine 
(Figure 1). This deposit is a volcanic-hosted massive sulfide deposit, similar to other submarine volcanic sequences (Petch 2004), located in the Archean High Lake Greenstone Belt (HLGB) in the northern Slave Structural Province, and is well within the zone of continuous permafrost. Permafrost depths at the site were estimated between 350 and 440 meters below ground surface (mbgs) based on exploration drilling (Pfiffner et al. 2008). The terrain around High Lake is rugged, with $>160 \mathrm{~m}$ of topographic variation. Prior to and during the study, only mineral exploration and site assessment activities occurred at the site, providing the opportunity to investigate relatively undisturbed permafrost conditions.

\section{Methods}

\section{Previous Work-Drilling}

Research activities began in July of 2006. The cost of drilling at this remote location exceeded the available budget, so a preexisting exploration borehole was selected for extension (HLW-03-28), with an existing length of $335 \mathrm{~m}$ (303.6 mbgs) from the collar at land surface and $65^{\circ}$ dip from horizontal (Pfiffner et al. 2008). Throughout this paper, borehole depth measurements in " $\mathrm{m}$ " refer to length in meters along the borehole from the collar (at land surface), and "mbgs" is the actual vertical depth of the measurement point in meters beneath ground surface.

Coring procedures and drill fluid tracer analysis were detailed by Pfiffner et al. (2008), but are briefly described here. As with all exploration boreholes previously drilled at the site, the borehole selected for extension was filled with ice formed from leftover drilling brine, vapor, and surficial meltwater. Prior to extending the borehole, the ice and frozen slough was drilled out over the course of $5 \mathrm{~d}$ using a $21 \% \mathrm{CaCl}_{2}$ brine heated to $80{ }^{\circ} \mathrm{C}$ to $90{ }^{\circ} \mathrm{C}$ by coil stoves. With drill rods still in the hole, hot fresh water was circulated for $5 \mathrm{~d}$ to flush out the $\mathrm{CaCl}_{2}$ brine. Despite using near boiling drill water, the return water was only $30^{\circ} \mathrm{C}$ to $35^{\circ} \mathrm{C}$. Research coring was then completed, using heated fresh drill fluid $\left(80{ }^{\circ} \mathrm{C}\right.$ to $90{ }^{\circ} \mathrm{C}$ ) with an NQ3 diamond drill bit, to a down-hole depth of $535 \mathrm{~m}$ (484.9 mbgs), for $200 \mathrm{~m}$ of additional core. The resulting borehole diameter was $75.7 \mathrm{~mm}$. The drillers estimated the base of the permafrost within the borehole at approximately $410 \mathrm{~m}$ (370 mbgs), based on previous drilling experience and drill performance. The fluid used for both freshwater research coring and for clearing ice (mixed with $\mathrm{CaCl}_{2}$ ) was obtained directly from Core Shed Lake; a nearby lake with low total dissolved conductivity (TDS) (electro conductivity [EC]: $4.9 \mathrm{mS} / \mathrm{m})$. The chemical composition of the research coring fluid can be found in Table 1, sample L19 (2006).

At the completion of drilling, the borehole was prepared for sampling. A "wet pull" was conducted, a procedure that removes as much drill fluid as possible by blocking the end of the drill string. A steel casing was then installed in the borehole to $320 \mathrm{~m}$ to maintain stability in the permafrost zone and prevent caving in several
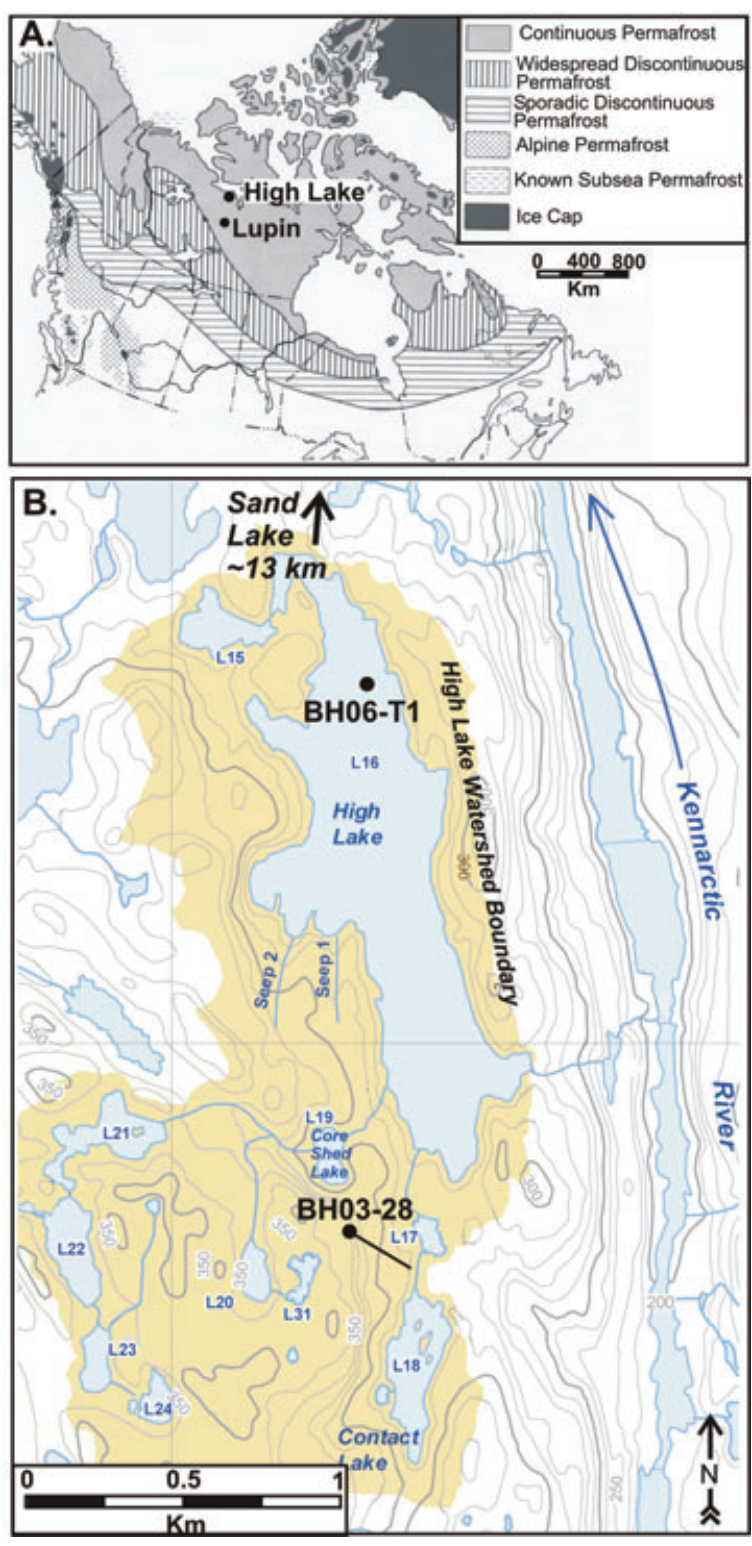

Figure 1. High Lake study location (A) in relation to Lupin mine and permafrost zones (after Natural Resources Canada 1995), and (B) topographic map of High Lake area (after Gartner Lee 2006c). The elevation countour interval is $10 \mathrm{~m}$. For this project, surface water samples were collected from the Kennearctic River, Sand Lake (off map), High Lake (L16), L18 (Contact Lake), L20, L21, L22, L31, and Core Shed Lake (L19). Water from Core Shed Lake was used as the drill fluid. Approximate surface trace of Borehole HLW03-28 is shown in black. The High Lake watershed is shaded.

intensively sheared zones (up to $6 \mathrm{~m}$ in length). A bailing operation was conducted to further clean out the drill water. An 18-L bailer was dropped 23 times, removing about $400 \mathrm{~L}$ of water, representing an uncased borehole fluid depth of $\sim 89 \mathrm{~m}$. Na/Ca and $\mathrm{Br} / \mathrm{Cl}$ ratios and $\delta^{37} \mathrm{Cl}$ values in bailed water were similar to the salt used to mix the drill brine for clearing the hole prior to drilling, and $\delta^{2} \mathrm{H}$ and $\delta^{18} \mathrm{O}$ values were similar to the fluid used during both research coring and ice clearing operations. It was suspected that the drill brine was forced into fractures 
Table 1

Summary of Water Chemistry and Isotope Results from Surface Water Bodies, High Lake talik, and U-tube samples

\begin{tabular}{|c|c|c|c|c|c|c|c|c|c|c|c|c|c|c|}
\hline Location & $\begin{array}{c}\mathrm{pH} \\
(\mathbf{L a b})\end{array}$ & $\begin{array}{c}\text { EC } \\
\mathrm{mS} / \mathrm{m}(\text { lab })\end{array}$ & $\begin{array}{c}\mathrm{Na} \\
\mathrm{mg} / \mathrm{L}\end{array}$ & $\underset{\mathrm{mg} / \mathrm{L}}{\mathrm{K}}$ & $\begin{array}{c}\mathrm{Ca} \\
\mathrm{mg} / \mathrm{L}\end{array}$ & $\begin{array}{c}\mathrm{Mg} \\
\mathrm{mg} / \mathrm{L}\end{array}$ & $\begin{array}{c}\mathrm{HCO}_{3} \\
\mathrm{mg} / \mathrm{L}\end{array}$ & $\begin{array}{c}\mathrm{SO}_{4} \\
\mathrm{mg} / \mathrm{L}\end{array}$ & $\begin{array}{c}\mathrm{Cl} \\
\mathrm{mg} / \mathrm{L}\end{array}$ & $\begin{array}{c}\mathrm{Br} \\
\mathrm{mg} / \mathrm{L}\end{array}$ & $\begin{array}{c}\delta^{18} \mathrm{O} \\
\% \text { VSMOW }\end{array}$ & $\begin{array}{c}\delta^{2} \mathbf{H} \\
\% o \text { VSMOW }\end{array}$ & $\begin{array}{c}\delta^{37} \mathrm{Cl} \\
\% \text { SMOC }\end{array}$ & $\begin{array}{r}{ }^{3} \mathbf{H} \\
\mathbf{T U}\end{array}$ \\
\hline \multicolumn{15}{|l|}{ Surface water } \\
\hline L18 & 7.4 & 4.5 & 1.7 & 2.4 & 7.5 & 2.8 & 23 & 10 & 5.2 & 0.049 & -21.0 & -166 & & 9.2 \\
\hline L19 $(2006)^{1}$ & 6.5 & 4.9 & 1.1 & 0.64 & 5.0 & 1.8 & 15.8 & 5.9 & 3.9 & $<0.1$ & -18.3 & -150 & & 11.7 \\
\hline L19 $(2007)^{1}$ & 7.1 & 7.6 & 1.3 & 1.4 & 6.0 & 1.1 & 23 & 3.4 & 1.5 & 0.021 & -18.7 & -152 & & 10.9 \\
\hline L20 & 6.7 & 11 & 2.1 & 1.1 & 11.7 & 3.3 & 25 & 4.0 & 16 & $<0.1$ & -17.1 & -145 & & 12 \\
\hline L21 & 6.4 & 2.2 & 0.83 & 0.45 & 2.5 & 0.77 & 11.6 & 1.2 & 1.5 & $<0.1$ & -17.6 & -146 & & 12 \\
\hline L22 & 6.5 & 3.9 & 1.3 & 0.75 & 4.2 & 1.5 & 18.3 & 2.6 & 2.5 & $<0.1$ & -17.6 & -145 & & 10.9 \\
\hline L31 & 6.8 & 15 & 1.9 & 1.5 & 18.9 & 3.7 & 33.6 & 9.9 & 21 & $<0.1$ & -14.7 & -132 & & 11.9 \\
\hline Sand Lake & NA & NA & NA & NA & NA & NA & NA & NA & NA & NA & -19.1 & -154 & & 9.6 \\
\hline Kennarctic River & 7.2 & 6.2 & 1.4 & 1.4 & 6.4 & 2.1 & 23 & 7.2 & 2.0 & 0.027 & -19.2 & -156 & & 9.8 \\
\hline L16 & 6.6 & 8.1 & 1.4 & 0.64 & 7.6 & 3.1 & 11.6 & 23 & 3.6 & $<0.1$ & -18.3 & -147 & & 11.2 \\
\hline L16B-B ${ }^{2}$ & 6.9 & 10.2 & 1.77 & 0.67 & 9.21 & 3.37 & 48 & 26.6 & 3.64 & - & NA & NA & & NA \\
\hline \multicolumn{15}{|l|}{ Talik } \\
\hline $\mathrm{BH} 06-\mathrm{T}^{2}$ & 7.4 & 13.2 & 3 & $<2.0$ & 14 & 4.5 & 53 & 34 & 4.9 & 0.050 & NA & NA & & NA \\
\hline \multicolumn{15}{|l|}{ U-tube } \\
\hline Purge 1 & 4.5 & 13500 & 111 & 29.8 & 37,500 & 41.2 & 1.22 & $<1000$ & 69,500 & 3.8 & -17.7 & -147 & & 11.9 \\
\hline Purge 4 & 4.9 & 4770 & 451 & 29.2 & 9810 & 36.1 & 3.05 & 39 & 19,400 & 6.1 & -22.2 & -175 & -0.5 & 5.8 \\
\hline Purge 6 & 4.8 & 3780 & 496 & 26.8 & 7210 & 32.7 & 4.27 & 33 & 14,300 & 7.2 & -22.5 & -177 & -0.4 & 4.4 \\
\hline Purge 7 & 5.3 & 3530 & 531 & 25.8 & 7540 & 31.0 & 4.27 & 25 & 13,100 & 7.5 & -22.6 & -177 & -0.6 & 4.8 \\
\hline Salt (mg/kg) & & & 6.2 & 33.3 & 241,000 & 156 & - & - & 374,000 & 4 & & & -0.4 & \\
\hline
\end{tabular}

during the 5-d period of fresh water cycling prior to research coring operations, with subsequent outflow into the borehole after cessation of drilling activities (Pfiffner et al. 2008).

A down-hole conductivity/water level probe was lowered into the borehole to monitor water levels and the rate of groundwater inflow during the 24-h period after the removal of the drill string. After $24 \mathrm{~h}$, the borehole became blocked with ice at $\sim 125 \mathrm{~m}$ (113 mbgs; depth determined with drill rods). From measurements taken the following year (in 2007), this was determined to be the part of the borehole with the most thermally conductive rock units. It is believed that this part of the permafrost column cooled more quickly and became the coldest portion along the borehole immediately following drilling. In turn, this section acted as a cold trap for water vapor in the borehole and fluid dripping from bailing and other down-hole instruments. The probe became locked in place within the borehole and eliminated the possibility for further water level measurements, even though a static water level had not been observed. At this point, the final water level measurement taken was $492 \mathrm{~m}$ (446 mbgs), and the fluid inflow rate was $\sim 1 \mathrm{~L} / \mathrm{h}$. Attempts to drill through the ice without drill fluid failed. Further work on the borehole was suspended until the following field season 12 months later in 2007.

\section{Ice Removal and Deep Borehole Assembly}

Field activities from the end of July through the beginning of August in 2007 focused on de-icing the borehole, installation of a U-tube geochemical sampling system, and obtaining samples (the U-tube sampling system will be described below). Upon arrival on site in July 2007, borehole ice was discovered at a much shallower depth $(2 \mathrm{~m})$. Recirculated hot $\left(90{ }^{\circ} \mathrm{C}\right.$ to $\left.98{ }^{\circ} \mathrm{C}\right)$, fresh water, from Core Shed Lake, with an uranine tracer, was used for drilling through the ice. The drill fluid was recirculated, such that once it returned to the surface, it was collected in a trough, then returned through the four coil heaters and back down the drill string. The only fluid added during drilling was from ice melting within the borehole. Although uranine was added at the beginning of drilling, concentrations in drill fluids were diluted during drilling due to melting of borehole ice. Thus, additional uranine was added to drill fluid before the final drill fluid sample was collected, just before the borehole was completely reopened. Eventually, cable from the probe lost in 2006 became wrapped around the drill bit, and the drill string had to be removed. The drill string was lowered, but the drill fluid remaining in the borehole had cooled, and the drill bit froze in place as drilling recommenced. Drill water of $98{ }^{\circ} \mathrm{C}$ was pumped down the borehole, but the return water was only $2{ }^{\circ} \mathrm{C}$. After a day of no progress thawing the drill, a $\mathrm{Ca}-\mathrm{Cl}$ salt solution was added to the drill fluid, and the bit was freed. Drilling with brine resumed without issue, and continued to $480 \mathrm{~m}$. The drill string was again removed using the "wet pull" technique. All fluid introduced to the borehole in both of the 2006 and 2007 field campaigns was drawn from Core Shed Lake.

A bottom-hole assembly (BHA) was installed to a packer depth of $465 \mathrm{~m} \mathrm{(421} \mathrm{mbgs)} \mathrm{within} 4 \mathrm{~h}$ of 


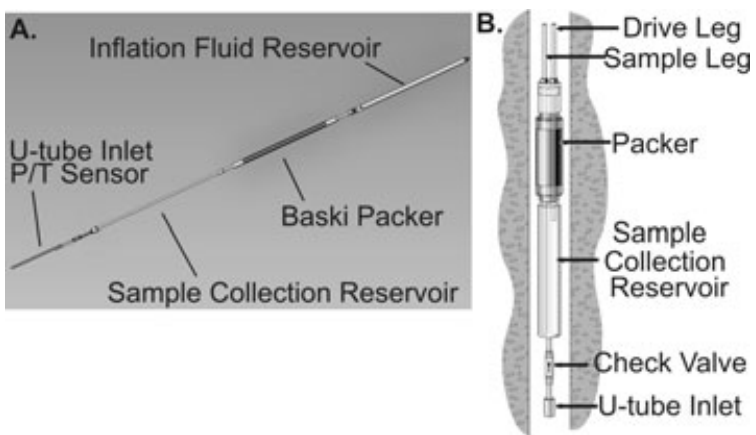

Figure 2. Diagram showing bottom-hole assembly (BHA) layout (A) and conceptual design for the U-tube sampler (B).

drill string removal (Figure 2A). The 14.9-m-long BHA contained one pneumatic packer, inflated with a $\mathrm{N}_{2}$ head over propylene glycol, a U-tube sampling system with a sample reservoir (described below) and a temperature/pressure sensor line (Freifeld et al. 2008b). The packer was installed in a section of borehole void of visible fractures in the core to isolate the bottom of the borehole, rather than a discrete interval. The BHA was lowered into the well using three 6.4-mm-diameter stainless steel tubes as a strength member to support the assembly; one which would also serve to inflate the packer, one as the U-tube $\mathrm{N}_{2}$ gas drive line and the final tube as the sample collection line. Heat tracer tape (14 AWG direct burial (outdoor) resistive electrical cable) was placed next to the stainless steel tubes to prevent freezing by providing uniform heating along the length of the borehole when current was applied. A high density poly-ethelyne (HDPE) jacketed multimode fiberoptic cable was installed along the sampling lines to a depth of $441 \mathrm{~m}$ (400 mbgs). The fiber-optic cable was interrogated using a distributed temperature sensor (DTS; Agilent Technologies Manufacturing GmbH \& Co. KG, Model N4385A, Böblingen, Germany). The DTS uses a laser backscattering technique to measure temperature with a 1-m spatial resolution along the length of the fiber. An overview of the DTS technology as applied to environmental monitoring can be found in the study of Selker et al. (2006). A cable also extended through the packer to a temperature-pressure transducer (LevelTroll 500, In-Situ Inc., Ft. Collins, Colorado) for measurements beneath the packer.

\section{Sample Collection}

The U-tube sampling approach has been used in several different environments and to a variety of depths (Freifeld et al. 2005; Freifeld 2009). Figure 2B displays the conceptual design for the High Lake U-tube sampler. The sample and drive legs terminate within a sample reservoir, forming a sample loop that is functionally identical to the "U"-loop of tubing in prior U-tube deployments (Freifeld 2009). Beneath the sample reservoir, a ball check valve, the only moving part of the sampling system, allows fluid from the formation to flow into the reservoir when the pressure in the borehole is greater than the pressure inside the sample reservoir. Samples are recovered using high pressure $\mathrm{N}_{2}$ gas applied to the drive leg, which closes the check valve and forces the fluid out of the fluid reservoir and up the sample leg to the surface. The U-tube installed at High Lake used a $40-\mu \mathrm{m}$ sintered stainless steel inlet filter and check valve located beneath the 7-L sample collection reservoir. When the tubing and sample reservoir have been fully flushed with $\mathrm{N}_{2}$ gas after sampling is concluded, venting of both the sample and drive leg allows the $\mathrm{N}_{2}$ gas to bleed off to atmospheric pressure and allows the check valve to open. The sample reservoir then fills again with borehole fluid. One advantage of the U-tube sampling system in permafrost is the capability to clean the sample and drive lines with $\mathrm{N}_{2}$ gas between sampling purges, removing fluid that could freeze in the sample line.

Groundwater and gas chemistry samples were collected in HDPE bottles and evacuated gas collection cylinders, respectively, during U-tube purging. Surface water samples were collected in HDPE bottles for geochemical analysis from the Kennarctic River and seven lakes within a $3 \mathrm{~km}$ radius of the borehole (High LakeL16, L18, Core Shed Lake-L19, L20, L21, L22, and L31), and Sand Lake, $\sim 16 \mathrm{~km}$ north (Figure 1B; Table 1). Lakes were numbered by the mining company and are labeled with "Ln," where $\mathrm{L}$ is the lake, and $n$ the identifying number for the lake. Fluid chemistry samples were filtered through a $0.2-\mu \mathrm{m}$ syringe filter, while isotope samples were unfiltered. Metal and trace element samples were preserved with $0.5 \mathrm{~mL}$ concentrated Suprapur ${ }^{\circledR}$ $\mathrm{HNO}_{3}$ (Merck Chemicals, Darmstadt, Germany) per $100 \mathrm{~mL}$ water.

\section{Matrix Fluid Analysis}

The crush and leach technique is a classic method for obtaining information about conservative ions $(\mathrm{Cl}, \mathrm{Br})$ in pore water (also known as matrix fluids) (Waber and Frape 2002; Smellie et al. 2003; Gaucher et al. 2006; Waber and Smellie 2008). Crush and leach is often also used to obtain information about other ions (e.g., cations) which may not be conservative. Concentrations of nonconservative species determined using crush and leach can be influenced by the dissolution of minerals or oxidation of the rock sample during the experimental procedure.

The matrix fluid analysis was conducted at Princeton University and was designed to determine the water chemistry of those pores that would be in diffusive contact with the hydraulically conductive fractures, defined as the diffusion porosity by Norton and Knapp (1977), and not that of the residual porosity or fluid inclusions. Rock core was selected during drilling from the lower portion of the borehole (where groundwater samples were ultimately collected). The core was coarsely crushed and leached with deionized (DI) water. The core was split into $20 \mathrm{~g}$ of $\sim 0.5 \mathrm{~cm}$ nuggets from the interior of the core and $20 \mathrm{~g}$ of $\sim 0.5 \mathrm{~cm}$ parings from the outer rim of the core using a custom made rock splitter. The combined $40 \mathrm{~g}$ of parings and nuggets were 
leached together with $40 \mathrm{~mL}$ of sterile degassed DI water in $50 \mathrm{~mL}$ Falcon tubes (Fisher Scientific, Pittsburgh, PA) for 2 days in an anaerobic glove bag (Coy Laboratory Products, Inc., Grass Lake, Michigan) filled with $\mathrm{H}_{2} / \mathrm{N}_{2}$ (10:90) mixture. Because the procedure was conducted under anaerobic conditions with degassed DI water, the results should not be affected by oxidation of any mineral phases (e.g., sulfides). The 2-day duration was to enable diffusive equilibrium to be achieved between the leachate and the pores within the rock chunk. Centrifugation for $15 \mathrm{~min}$ at $3400 \mathrm{rpm}$ allowed the pore water leachate to be removed and stored in a serum vial at $-20{ }^{\circ} \mathrm{C}$. The anions, including the carboxylic acids, were measured by ion chromatography (IC) (DX-320, Dionex, Sunnyvale, California) using EG40 (eluent generator) and LC25 (liquid chromatograph) columns and an AS40 autosampler calibrated by a 4-point curve. Cations were measured by inductively coupled plasma optical emission spectroscopy (ICP-OES) (Optima 4300 DV, Perkin Elmer, Waltham, Massachusetts) calibrated with a 4-point curve. Trace metal cations for selecting cores were measured by inductively coupled plasma mass spectrometry (ICP-MS) $(6100$ ICP-MS Perkin Elmer, Waltham, Massachusetts) at Activation Laboratories, Ltd., Ontario, Canada. The dissolved inorganic carbon (DIC) was determined by addition of phosphoric acid to the sealed serum vials after removing the cation and anion samples, purging the $\mathrm{CO}_{2}$ with high purity $\mathrm{N}_{2}$ and measurement of $\mathrm{CO}_{2}$ gas concentration by infrared adsorption (LI-6252, LiCOR Biosciences, Lincoln, Nebraska). The detection limit was $0.05 \mathrm{ppm}$ with a relative standard deviation of $1 \%$ based on a 3-point calibration curve. Sulfide samples were quantified by ultraviolet (UV) spectroscopy following the method of Cord-Ruwisch (1985). Trace gas analyses of the matrix fluid were attempted by sealing cores in evacuated, stainless steel cylinders, but no gases were detected after 6 weeks (Pfiffner et al. 2008). Free energy calculations were made for methanogenic and $\mathrm{SO}_{4}{ }^{2-}$ reducing reactions using Geochemist's Workbench (RockWare Inc., Golden, Colorado). Representative 1-inch diameter subcores were drilled from five cores and sent to Core Petrophysics Inc. (Houston, Texas) for He-porosity measurements. Cores from the same depth intervals were sent to LawrenceBerkley National Laboratory (LBNL) for DNA extraction and sequencing.

Eight separate sections of a core were selected for investigation of matrix salinity above the groundwater sampling zone at the University of Waterloo (UW), with a different approach to the crush and leach methodology. Crush and leach techniques and rationale used were the same as those followed at the Lupin Au Mine (Stotler et al. 2009) and are detailed by Frape et al. (2004), Smellie et al. (2003), and Waber and Smellie (2008). Briefly summarized, rock core was quickly rinsed in DI water, then crushed $(<63 \mu \mathrm{m})$, weighed and added to double-DI nano-pure water in a solid to liquid ratio of $1 \mathrm{~g}$ to $1 \mathrm{~mL}$. The mixture was put on a shaker for $24 \mathrm{~h}$. The solution was then extracted from the rock particles by vacuum sieve. For the calculation of mass-solute-per-kg-of-rock, it was assumed all available $\mathrm{Cl}^{-}$was released into the fluid phase during the 24-h reaction period, which had proved sufficient after repeated leaching of samples in previous studies (Smellie et al. 2003; Waber and Smellie 2008). Core was carefully selected throughout the length of borehole column to avoid visible fracture (e.g., calcite) or quartz minerals that could dissolve or contain higher concentrations of potentially saline fluid inclusions. Selected core included sections previously drilled by the mining company to analyze fluids from similar rock types throughout the rock column to investigate the influence of permafrost on matrix fluids.

\section{Chemical Analyses}

Surface water, groundwater, and matrix fluid samples were analyzed for major and trace elements. Ionic analyses occurred in the Geolaboratory of the Geological Survey of Finland (GTK). Total alkalinity (as mmol $\mathrm{HCO}_{3} / \mathrm{L}$ ) was determined in the laboratory using an automatic titrator. No adjustments were made for atmospheric $\mathrm{CO}_{2}$ diffusion during the transport period of 2 to 4 weeks. The anions $\left(\mathrm{F}^{-}, \mathrm{Br}^{-}, \mathrm{Cl}^{-}, \mathrm{NO}_{3}{ }^{-}\right.$, and $\left.\mathrm{SO}_{4}{ }^{2-}\right)$ were analyzed using ion chromatography (IC). All cations and other elements were analyzed by inductively coupled plasma-atomic emission spectroscopy (ICP-AES) or ICPMS technique. The ICP detection limits for $\mathrm{Ca}^{2+}, \mathrm{Na}^{+}$, $\mathrm{K}^{+}, \mathrm{Mg}^{2+}, \mathrm{Li}^{+}$, and $\mathrm{Sr}^{2+}$ were $100,200,10,100,0.1$, and $0.1 \mu \mathrm{g} / \mathrm{L}$, respectively. Charge balance errors in the samples reported are below $10 \%$.

Gas compositions were analyzed at the UW Organic Geochemistry Laboratory; $\mathrm{N}_{2}$ and $\mathrm{CO}_{2}$ on a Fisher/ Hamilton Gas Partitioner, Model 29 gas chromatograph, and alkane-hydrocarbons on a Varian 3800 gas chromatograph equipped with a flame ionization detector and capillary injection port. Detection limits for $\mathrm{CO}_{2}, \mathrm{~N}_{2}, \mathrm{C}_{1}, \mathrm{C}_{2}$, $\mathrm{C}_{3}, \mathrm{nC}_{4}$, and $\mathrm{iC}_{4}$ are $0.5,30 \mathrm{ppm}, 0.3,0.2,0.2,0.8$, and $1.6 \mu \mathrm{g} / \mathrm{L}$, respectively.

In order to determine the vertical distribution of microbial sulfate reduction activity, ${ }^{35} \mathrm{~S}$ microautoradiography was performed at Princeton University following the procedure of Krumholz et al. (1997) on 18 cores from 340 to $530 \mathrm{~m}$ depth. Ag foils were pretreated by consecutive washing with ethanol, acetone, and hexane, before being oxidized with concentrated nitric acid and then autoclaved. Ball wide mouth half-gallon mason jars, containing 15-cm-long rock cores were placed inside a Coy anaerobic glove bag with the Ag foils. The cores were then removed from the Mason jars and their Whirl-Pak ${ }^{\circledR}$ (Nasco, Fort Atkinson, Wisconsin) bags. The outside surfaces of the cores were irradiated with a UV wand as a means of deactivating any surface contaminants that may have appeared during shipping or within the glove bag. The core was quickly split and $100 \mu \mathrm{L}$ of $10 \mu \mathrm{Ci}{ }^{35} \mathrm{SO}_{4}$ was added to each fracture surface. Because the cores often had a metamorphic foliation, the fracture occurred at an oblique angle to the core axis. Ag foil was sandwiched between the fracture surface and the two ends of the core taped together. The core was then slid into 
clear, sterile polyvinyl chloride (PVC) tubing and the ends packed with autoclaved paper and wrapped with duct tape so that the fracture surfaces would press tightly against the Ag foil. The PVC tubes were returned to their Mason jars, CampyPak ${ }^{\mathrm{TM}}$ (BD Diagnostics, Sparks, Maryland) were added and activated; the jars were then sealed and placed in a refrigerator where they were incubated for $\sim 120$ days at $4{ }^{\circ} \mathrm{C}$. Three cores were baked at $500{ }^{\circ} \mathrm{C}$ for $24 \mathrm{~h}$ in $\mathrm{Al}$ foil and then processed in the same manner in order to evaluate procedural blanks. After incubation, the Ag foils were removed from the cores and imaged with a Storm Geo 860 Scanner (Molecular Dynamics, California). The rate of sulfate reduction was calculated for each "hot spot" of AgS by quantification of the imager response with standards and using the formula presented by Kallmeyer et al. (2004).

Tritium, $\delta^{2} \mathrm{H}, \delta^{18} \mathrm{O}$, and $\delta^{37} \mathrm{Cl}$ were analyzed at the UW Environmental Isotope Laboratory. Tritium values were determined by the electrolytic enrichment method of Taylor (1977), and counted in a LKB Wallac 1220 Quantalus liquid scintillation counter, with a detection limit of 0.8 T.U. Deuterium determinations were made following the $\mathrm{Mn}$ reduction preparation method of Shouakar-Stash et al. (2000) and the $\mathrm{Cr}$ reduction method of Morrison et al. (2001), and analyzed on an Isoprime IRMS coupled with a Eurolecton elemental analyzer. Oxygen isotope analysis was performed on a Micromass 903 triple collector mass spectrometer using the preparation procedures of Epstein and Mayeda (1953) with Moser's (1977) modification. Analytical reproducibility of $\delta^{18} \mathrm{O}$ and $\delta^{2} \mathrm{H}$ are $\pm 0.2 \%$ ond $\pm 2.0 \%$ o respectively. Dissolved $\mathrm{Cl}^{-}$was converted to $\mathrm{CH}_{3} \mathrm{Cl}$ and analyzed for $\delta^{37} \mathrm{Cl}$ on a dual inlet Isoprime IRMS following the method of Eggenkamp (1994), with an accuracy of $\pm 0.15 \%$.

\section{Results}

After installation of the BHA, the U-tube was successfully purged seven full times before sample lines froze, with samples for aqueous chemistry collected during purges $1,4,6$, and 7 , and for gas chemistry during purges 4 and 6, all obtained within a week of installation. Chemical results from these analyses are described below. Despite freezing, sample collection time was increased by $4 \mathrm{~d}$, or $400 \%$, over past efforts in this environment. In total, $64.96 \mathrm{~L}$ of water was removed (Table 2), a small portion of the volume in the borehole beneath the packer ( $\sim 315 \mathrm{~L})$. Thus, $\sim 20 \%$ of the fluid beneath the borehole was removed during $4 \mathrm{~d}$ of U-tube purging operations. Down-hole temperature measurements were obtained with both the DTS and the single point temperature-pressure transducer, which also obtained pressure measurements. Both of these instruments were still operational a month after installation; the last time someone was available to collect measurements. Numerous down-hole physical measurements were successfully obtained using these instruments, including rock temperature and thermal conductivity, hydraulic head, and hydraulic conductivity, which are described in the following text.

\section{Fluid Chemistry}

Surface water had a distinct chemical makeup compared with the groundwater samples. The surface water survey sampled low salinity, $\mathrm{Ca}-\mathrm{SO}_{4}$ to $\mathrm{Ca}-\mathrm{HCO}_{3}$ type water, similar to lake chemistry surveys previously

\begin{tabular}{|c|c|c|c|c|c|c|c|c|}
\hline \multicolumn{9}{|c|}{$\begin{array}{c}\text { Table } 2 \\
\text { Uranine Concentrations and Tritium Activity from Drill and U-Tube Samples }\end{array}$} \\
\hline \multirow[b]{2}{*}{ Sample } & \multirow[b]{2}{*}{ Date } & \multirow[b]{2}{*}{ Time } & \multirow[b]{2}{*}{ Volume Purged (L) } & \multirow[b]{2}{*}{ pH } & \multicolumn{2}{|r|}{ Uranine } & \multicolumn{2}{|c|}{ Tritium } \\
\hline & & & & & $\overline{(\mu \mathrm{g} / \mathrm{L})}$ & $\%$ Drill Fluid $^{1}$ & (TU) & $\%$ Drill Fluid $^{2}$ \\
\hline HL drill water & 25-Jul-2007 & $3: 28$ & & & 27,300 & & NA & \\
\hline HL drill water & 27-Jul-2007 & - & & & 10,200 & & NA & \\
\hline HL drill water & 29-Jul-2007 & $2: 10$ & & & 3500 & & NA & \\
\hline HL drill water & 29-Jul-2007 & $7: 30$ & & & 10,100 & & $10.9-11.7^{3}$ & \\
\hline Purge 1 (HL-GTK-29) & 30-Jul-2007 & $11: 40$ & 13.60 & 5.43 & 3700 & $36 \%-100 \%$ & 11.9 & $100 \%$ \\
\hline Purge 2 & 30-Jul-2007 & $19: 42$ & 7.96 & 6.50 & NA & & NA & \\
\hline Purge 3 & 31-Jul-2007 & $13: 52$ & 10.57 & 8.56 & NA & & NA & \\
\hline Purge 4 (HL-GTK-30) & 1-Aug-2007 & $10: 41$ & 9.63 & 6.69 & 1400 & $14 \%-38 \%$ & 5.8 & $49 \%$ \\
\hline Purge 5 & 1-Aug-2007 & $21: 15$ & 6.81 & 7.76 & NA & & NA & \\
\hline Purge 6 (HL-GTK-31) & 2-Aug-2007 & $11: 00$ & 6.27 & 7.25 & 710 & $7 \%-19 \%$ & 4.4 & $37 \%$ \\
\hline Purge 7 (HL-GTK-32) & 2-Aug-2007 & $21: 25$ & 7.84 & 8.50 & 880 & $9 \%-24 \%$ & 4.8 & $40 \%$ \\
\hline Purge 8 & 3-Aug-2007 & $9: 50$ & 2.28 & 9.15 & NA & & NA & \\
\hline \multicolumn{9}{|c|}{$\begin{array}{l}{ }^{1} \text { The low value represents } \% \text { drill fluid, calculated from the final drill fluid sample, the higher value is the } \% \text { drill fluid as calculated from the first purged sample } \\
\text { and is considered an upper limit. } \\
{ }^{2} \text { Tritium values are typically } \pm 0.6 \text {. Thus, } \% \text { drill fluid calculations are within } \pm 7 \% \text {. Decay of tritium from fluids added in } 2006 \text { is not considered. } \% \text { drill fluid is } \\
\text { based on drill water tritium value of } 11.7 \mathrm{TU} \text {. } \\
{ }^{3} \text { Tritium was measured in two separate Core Shed Lake samples, the source for drill water, not the circulating return water. } \\
\text { NA = not analyzed. }\end{array}$} \\
\hline
\end{tabular}


conducted in the area by the Geological Survey of Canada and Wolfden Resources (Cameron and Ballantyne 1975; Gartner Lee Ltd. 2006c, 2006d). A talik water sample from $44.5 \mathrm{~m}$ beneath High Lake (BH06-T1) revealed the relatively shallow talik water was chemically similar to surface water (Table 1; Gartner Lee Ltd. 2006b). One High Lake water sample (L16B-B) was obtained at the same time as the talik sample in April 2006. Conductivity, $\mathrm{pH}$, and major ions were all slightly higher in the talik groundwater sample (Table 1; Gartner Lee Ltd. 2006b). Bailed water and U-tube samples were $\mathrm{Ca}-\mathrm{Cl}$ type water. Salinity decreased dramatically during the seven U-tube purges $(13,500$ to $3530 \mathrm{mS} / \mathrm{m}$, Table 1$)$. Purge 1 contained a high amount of $\mathrm{Ca}(37,500 \mathrm{mg} / \mathrm{L})$ and salinity $(107,000 \mathrm{mg} / \mathrm{L})$ with low $\mathrm{Na}(111 \mathrm{mg} / \mathrm{L})$, reflecting the Ca-salt drilling fluid used at High Lake. By purge 7 , decreased $\mathrm{Ca}$ and salinity was observed (7540 and 21,200 mg/L), associated with increased $\mathrm{Na}$ concentrations $(531 \mathrm{mg} / \mathrm{L})$.

Stable isotopic values of all surface water and groundwater samples from the High Lake site plot near the global meteoric waterline (GMWL) (Figure 3). The $\delta^{2} \mathrm{H}$ and $\delta^{18} \mathrm{O}$ values in the surface water varied between
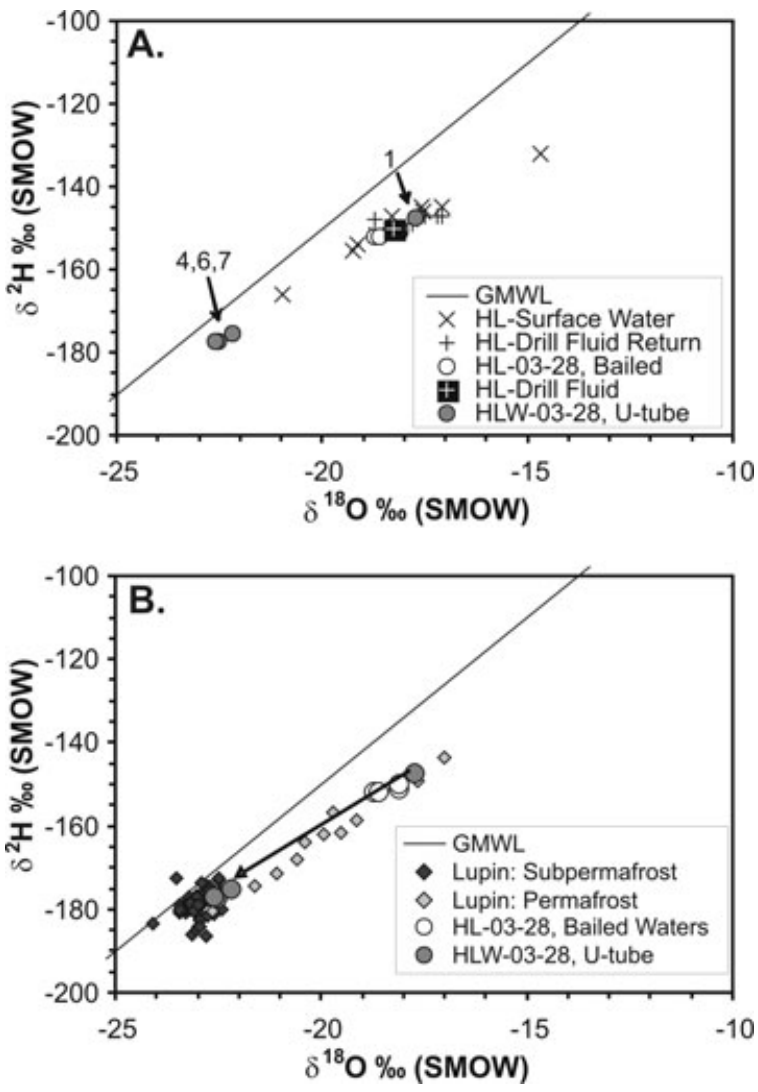

Figure 3. Stable isotopic composition of High Lake water (A) and compared with Lupin water (B). The first U-tube sample (1) had a similar isotopic composition as High Lake surface water and the bailed fluids, however purge samples 4, 6, and 7 had a similar isotopic composition as Lupin subpermafrost and deep permafrost. Arrow indicates the direction of successive U-tube sampling. Lupin data are from Stotler et al. (2009).
Table 3

Gas Composition from HLW-03-28

\begin{tabular}{|lcc|}
\hline Parameter & $\begin{array}{c}\text { HLW-03-28, } \\
\text { Purge 4 }\end{array}$ & $\begin{array}{c}\text { HLW-03-28, } \\
\text { Purge 6 }\end{array}$ \\
\hline \% Oxygen & 0.60 & $6.65-12.81$ \\
\% Nitrogen & 93 & 84 \\
\% Carbon Dioxide & 0.05 & 0.06 \\
\% Methane & 0.0729 & 0.35 \\
\% Ethene & 0.0001 & 0.0002 \\
\% Ethane & 0.0014 & 0.0062 \\
\% Propene & 0.0001 & 0.0001 \\
\% Propane & 0.0002 & 0.0001 \\
\% Butene & $\mathrm{ND}$ & 0.0001 \\
\% iso-Butane & 0.0001 & 0.0001 \\
\% Butane & 0.0001 & 0.0002 \\
C1/(C2 $+\mathrm{C} 3)$ & 46 & 56 \\
\hline
\end{tabular}

$-166 \%$ and $-132 \%$ VSMOW (Vienna Standard Mean Ocean Water), and $-21.0 \%$ and $-14.7 \%$ VSMOW, respectively. Bailed water had similar values as the drill water obtained from Core Shed Lake $(-151 \%$ V VSMOW and $-18.3 \%$ VSMOW, respectively). U-Tube sample $\delta^{2} \mathrm{H}$ and $\delta^{18} \mathrm{O}$ values decreased from drill water values with each successive purge, to minimum values of $-177 \%$ o VSMOW and $-22.5 \%$ VSMOW, similar to basal and subpermafrost fluids sampled at the Lupin $\mathrm{Au}$ Mine (Stotler et al. 2009).

Trace amounts of gas were found in both of the U-tube gas samples that were collected (Table 3). At the time of analysis, the sample from purge 6 was not under positive pressure and was leaking, as evidenced by the presence of $\mathrm{O}_{2}(6 \%$ to $12 \%)$ in this sample. The large amount of $\mathrm{N}_{2}$ in both samples ( $84 \%$ to $93 \%$ ) was likely due to the use of $\mathrm{N}_{2}$ to force the sample to the surface for collection. The negligible amount of $\mathrm{O}_{2}$ (purge 4) indicated the $\mathrm{CH}_{4}$ detected in this sample was naturally occurring, and not introduced by drilling. The ratio of $\mathrm{CH}_{4}$ to $\mathrm{C}_{2} \mathrm{H}_{6}$ and $\mathrm{C}_{3} \mathrm{H}_{8}(\mathrm{C} 1 /(\mathrm{C} 2+\mathrm{C} 3))$ was 46 and 56 for purges 4 and 6 , respectively (Table 3 ).

Measured chemical compositions from the matrix fluids obtained by the crush and leach method are shown in Table 4 and Figure 4. The He-porosity measurements ranged from $0.16 \%$ to $0.70 \%$. Using these porosities and a bulk density of $2.7 \mathrm{~kg} / \mathrm{L}$, the estimated pore water concentrations for $\mathrm{Na}^{+}, \mathrm{Ca}^{2+}, \mathrm{Mg}^{2+}, \mathrm{Cl}^{-}$, and $\mathrm{Br}^{-}$(geometric mean $\pm 1 \sigma$ ) from the Princeton methodology were 6200(+4000/-2400), 5200(+3200/-2000), 166(+93/-60), 820(+1040/-460), and 6(+4/-2) mg/L respectively, and for the UW methodology were 14,500 $(+6200 /-4300), 3700(+14,000 /-3100), 2100(+3700 /$ $-1100), 7500(+7500 /-3100)$, and $77(+31 /-22) \mathrm{mg} / \mathrm{L}$, respectively, and did not exhibit any trend with depth. Uncertainty in individual core porosity resulted in a $22 \%$ uncertainty in reported matrix fluid ionic concentrations (for the UW method). $\mathrm{SO}_{4}{ }^{2-}$ and $\mathrm{HCO}_{3}{ }^{-}$ concentrations from the Princeton methodology averaged $190(+100 /-60)$ and $50 \pm 9 \mathrm{mg} / \mathrm{L}$, respectively, and were 
Table 4

Calculated Concentrations of Major Ions in Crush and Leach Samples as mg/kg (ppm), Borehole HLW-03-28

\begin{tabular}{|c|c|c|c|c|c|c|c|c|c|c|c|c|c|c|c|c|}
\hline $\begin{array}{l}\text { Depth } \\
\text { m }\end{array}$ & $\begin{array}{c}\text { B } \\
\mathrm{mg} / \mathrm{kg}\end{array}$ & $\begin{array}{c}\mathrm{Li} \\
\mathrm{mg} / \mathrm{kg}\end{array}$ & $\begin{array}{c}\mathrm{Mn} \\
\mathrm{mg} / \mathrm{kg}\end{array}$ & $\begin{array}{c}\mathrm{Sr} \\
\mathrm{mg} / \mathrm{kg}\end{array}$ & $\begin{array}{c}\mathrm{Fe} \\
\mathrm{mg} / \mathrm{kg}\end{array}$ & $\begin{array}{c}\mathrm{Na} \\
\mathrm{mg} / \mathrm{kg}\end{array}$ & $\begin{array}{c}\mathrm{K} \\
\mathrm{mg} / \mathrm{kg}\end{array}$ & $\begin{array}{c}\mathrm{Ca} \\
\mathrm{mg} / \mathrm{kg}\end{array}$ & $\begin{array}{c}\mathrm{Mg} \\
\mathrm{mg} / \mathrm{kg}\end{array}$ & $\begin{array}{c}\mathrm{Br} \\
\mathrm{mg} / \mathrm{kg}\end{array}$ & $\begin{array}{c}\mathrm{Cl} \\
\mathrm{mg} / \mathrm{kg}\end{array}$ & $\begin{array}{c}\mathrm{SO}_{4} \\
\mathrm{mg} / \mathrm{kg}\end{array}$ & $\begin{array}{c}\mathrm{HCO}_{3} \\
\mathrm{mg} / \mathrm{L}\end{array}$ & $\begin{array}{c}\text { Formate } \\
\mathrm{mg} / \mathrm{kg}\end{array}$ & $\begin{array}{c}\text { Acetate } \\
\mathrm{mg} / \mathrm{kg}\end{array}$ & $\begin{array}{c}\delta^{37} \mathrm{Cl} \\
\% \text { SMOC }\end{array}$ \\
\hline $30.36^{1}$ & 0.27 & 0.0148 & 0.0128 & 0.02 & 1.25 & 67.4 & 49.7 & 4.31 & 2.09 & 0.24 & 29.60 & 26.3 & NA & NA & NA & 0.4 \\
\hline $68.70^{1}$ & 0.15 & 0.0121 & 0.0181 & 0.01 & 1.19 & 42.1 & 139 & 1.34 & 1.75 & 0.24 & 20.91 & 14.7 & NA & NA & NA & -0.3 \\
\hline $102.32^{1}$ & 0.31 & 0.0469 & 0.0019 & 0.04 & $<0.03$ & 58.9 & 115 & 26.4 & 12.8 & 0.30 & 37.50 & 123 & NA & NA & NA & 1.2 \\
\hline $116.10^{1}$ & 0.33 & 0.0118 & 0.0031 & 0.03 & $<0.03$ & 30.5 & 125 & 26.0 & 6.68 & 0.24 & 32.17 & 131 & NA & NA & NA & -0.2 \\
\hline $199.48^{1}$ & 0.04 & 0.0007 & 0.0008 & 0.04 & $<0.03$ & 16.9 & 19.1 & 5.95 & 21.2 & 0.07 & 7.10 & 2.60 & NA & NA & NA & 0.1 \\
\hline $288.93^{1}$ & 0.17 & 0.0178 & 0.0719 & 0.89 & $<0.03$ & 38.3 & 34.8 & 724 & 50.8 & 0.29 & 24.59 & 1999 & NA & NA & NA & 0.4 \\
\hline $308.14^{2}$ & & 0.0041 & 0.0247 & 0.02 & $<0.02$ & 2.8 & 0.80 & 22.3 & 0.54 & 0.006 & 0.94 & 0.38 & 37.2 & 1.30 & 6.16 & NA \\
\hline $310.95^{1}$ & 0.10 & 0.0004 & 0.0009 & 0.01 & 0.08 & 33.1 & 57.2 & 2.57 & 2.66 & 0.16 & 13.38 & 8.39 & NA & NA & NA & 0.9 \\
\hline $325.18^{1}$ & 0.25 & 0.0014 & 0.0159 & 0.01 & 0.86 & 37.1 & 102 & 1.67 & 0.84 & 0.19 & 11.40 & 4.80 & NA & NA & NA & -0.2 \\
\hline $327.17^{2}$ & & 0.0069 & 0.0017 & 0.02 & $<0.02$ & 26.0 & 6.50 & 11.4 & 0.63 & 0.009 & 0.47 & 0.17 & 60.7 & 1.00 & 4.68 & NA \\
\hline $346.21^{2}$ & & 0.0036 & 0.0098 & 0.03 & $<0.02$ & 7.5 & 2.79 & 22.6 & 0.49 & 0.005 & 1.00 & 0.31 & 44.4 & 1.20 & 5.47 & NA \\
\hline $355.27^{2}$ & & 0.0032 & 0.0142 & 0.02 & $<0.02$ & 6.6 & 2.79 & 20.1 & 0.33 & 0.005 & 0.85 & 0.28 & 50.9 & 1.07 & 5.72 & NA \\
\hline $365.24^{2}$ & & 0.0056 & 0.0026 & 0.03 & $<0.02$ & 12.4 & 8.72 & 18.0 & 0.47 & 0.008 & 0.51 & 0.20 & 51.0 & 1.11 & 5.44 & NA \\
\hline $384.27^{2}$ & & 0.0035 & 0.0017 & 0.02 & 0.05 & 34.1 & 2.04 & 7.0 & 0.30 & 0.007 & 0.79 & 0.29 & 60.8 & 1.29 & 12.58 & NA \\
\hline $403.31^{2}$ & & 0.0047 & 0.0047 & 0.02 & $<0.02$ & 18.8 & 1.64 & 9.2 & 0.24 & 0.005 & 0.58 & 0.37 & 48.5 & 1.17 & 4.62 & NA \\
\hline $422.34^{2}$ & & 0.0035 & 0.0043 & 0.02 & 0.21 & 22.6 & 5.83 & 8.8 & 0.35 & 0.005 & 1.78 & 1.15 & 49.1 & 1.03 & 5.31 & NA \\
\hline $441.37^{2}$ & & 0.0037 & 0.0088 & 0.03 & $<0.02$ & 15.5 & 1.97 & 18.5 & 0.66 & 0.007 & 1.02 & 0.50 & 56.3 & 1.14 & 6.06 & NA \\
\hline $455.87^{2}$ & & 0.0036 & 0.0058 & 0.03 & $<0.02$ & 19.9 & 15.2 & 20.6 & 1.43 & 0.011 & 1.35 & 2.16 & 30.7 & 1.22 & 10.49 & NA \\
\hline $460.40 *$ & & 0.0058 & 0.0066 & 0.04 & $<0.02$ & 19.2 & 11.2 & 12.5 & 0.31 & 0.006 & 2.23 & 4.35 & 43.8 & 1.52 & 10.98 & NA \\
\hline
\end{tabular}

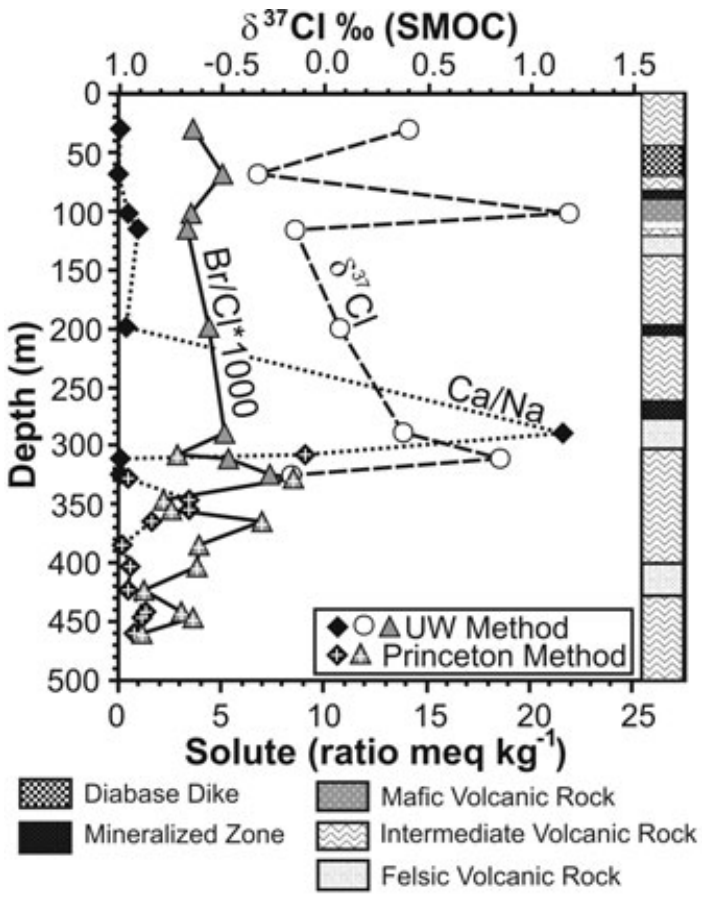

Figure 4. Profiles of calculated ionic ratios (meq/kg) and $\delta^{37} \mathrm{Cl}$ values in matrix fluids along the borehole in HLW03-28. The borehole log is displayed along the $y$-axis for comparison.

also fairly uniform with depth; whereas acetate concentrations increased from $\sim 1770$ to $14,750 \mathrm{mg} / \mathrm{L}$ and formate concentrations increased from $\sim 450$ to $1800 \mathrm{mg} / \mathrm{L}$ with depth. $\mathrm{NO}_{3}{ }^{-}$was less than the detection limit of
$0.003 \mathrm{mg} / \mathrm{L}$, equivalent to $\sim 2 \mathrm{mg} / \mathrm{L}$ for the pore fluid concentration. The $\mathrm{Cl}^{-}$and $\mathrm{Br}^{-}$concentrations from the Princeton leach was 10 times less than that of the UW leach, consistent previous experiments that have shown that a smaller crushed grain size is required to free all $\mathrm{Cl}^{-}$ ions from pore spaces (Smellie et al. 2003), and with exclusion of conservative anions from submicron pores. The $\mathrm{Br} / \mathrm{Cl}$ ratio was consistent between the two approaches. The $\mathrm{Mg}^{2+}$ concentrations from the Princeton leach was 40 times less than that of the UW leach, but consistent with the $\mathrm{pH}$ of 10 to 11 determined for the pore water from $\mathrm{pH}$ measurements of the Princeton leachates and assuming $\mathrm{Mg}^{2+}$ equilibrium with gibbsite. Some calculated solute concentrations were extraordinarily high, particularly $\mathrm{K}^{+}$and $\mathrm{SO}_{4}{ }^{2-}$ from the UW leaching method, likely resulting from sulfide oxidation during core storage and leaching. Rock porosity was only measured in rock collected below 310 mbgs; if higher porosities were present higher in the rock column, matrix fluid concentrations would be lower. Thus, later discussion will focus on relative, rather than absolute, solute concentrations. The $\delta^{37} \mathrm{Cl}$ values $(-0.3 \%$ o to $1.2 \%$ o SMOC [Standard Mean Ocean Chloride]) of matrix fluids did not vary systematically with depth along the borehole (Figure 4).

The ${ }^{35} \mathrm{SO}_{4}{ }^{2-}$ reduction rates ranged from $10^{-4}$ to $10^{-1} \mathrm{nmol} / \mathrm{cm}^{3} /$ day and appear to increase with increasing depth, whereas the rates for the control cores ranged from $10^{-6}$ to $10^{-3} \mathrm{nmol} / \mathrm{cm}^{3} /$ day (Figure 5). At $340 \mathrm{~m}$ depth, the average ${ }^{35} \mathrm{SO}_{4}{ }^{2-}$ reduction rates were 10 times that of the control cores, whereas at $508 \mathrm{~m}$ depth, the average ${ }^{35} \mathrm{SO}_{4}{ }^{2-}$ reduction rates were 1000 times that of the control cores. 


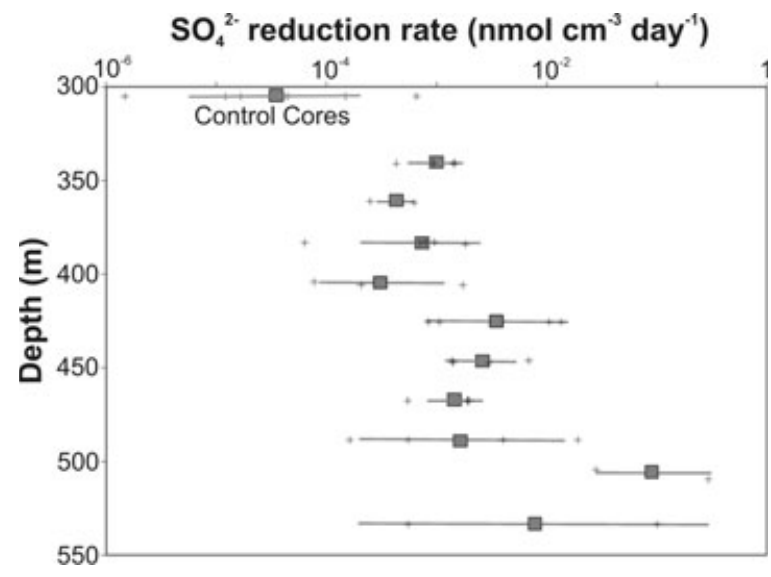

Figure 5. ${ }^{35} \mathrm{SO}_{4}{ }^{2-}$ reduction rates in $\mathrm{nmol} / \mathrm{cm}^{3} /$ day vs. depth (crosses). Geometric mean and standard deviation (gray square and line). Control cores are arbitrarily positioned at $305 \mathrm{~m}$ depth for comparison and do not reflect their true depth.

\section{Temperature}

The results of a distributed temperature perturbation sensor (DTPS) experiment, conducted over a span of $5 \mathrm{~d}$, with $64 \mathrm{~h}$ of heating and $58 \mathrm{~h}$ of cooling are given in Figure 6 . Thermal conductivity values along the borehole were calculated from these data by Freifeld et al. (2008a) (Figure 6B). During DTPS experiments, at the peak of heating, the coldest part of the borehole was $-2{ }^{\circ} \mathrm{C}$; and the upper $275 \mathrm{~m}$ of the borehole remained below freezing $\left(0^{\circ} \mathrm{C}\right)$ (Figure 6). Significantly, the coldest section prior to heating was not the coldest section at the peak of heating. Rather, the coldest sections at the peak of heating ( $48 \mathrm{~h}$ ) corresponded to a zone of high thermal conductivity (Figure 6) in the metallic ore zone (150 to $200 \mathrm{~m}$ ), well below where the thermal minimum occurred in undisturbed conditions. DTS temperature measurements were extrapolated to indicate the base of the permafrost at $440 \pm 5 \mathrm{mbgs}(485 \mathrm{~m})$, deeper than suspected from the performance of the drilling rig, and below the U-tube sampling point (Freifeld et al. 2008a).

\section{Groundwater Elevation}

The equilibrium subpermafrost piezometric pressure was estimated using a Horner Plot, a technique commonly used in the oil industry when steady state is not observed during recovery (Streltsova 1988). Pressure is plotted as a function of $\log _{\mathrm{e}}\left(t /\left(t_{s}\right)\right)$, where $t$ is the time elapsed since start of pumping (or pressure perturbation) and $t_{s}$ is the time since of the end of pumping, or in this case pressure perturbation due to a U-tube sampling event. Using the pressure data from the level troll pressure-temperature sensor, the pressure at a depth of $430 \mathrm{mbgs}$ was 3420 $\mathrm{kPa}, 1$ month after installation and sampling of the BHA. This value is equivalent to a freshwater head at $\sim 349 \mathrm{~m}$ above the sampling point, or $81 \mathrm{mbgs}(\sim 260 \mathrm{~m}$ above sea level, ASL). As observed in the progressive U-tube samples, total salinity was decreasing, indicating a fresh or brackish fluid was mixing into the fluid. Borehole fluid densities for the final pressure measurements (1 month after geochemical sampling) could thus range between the final sampled value $\left(\sim 1.021 \mathrm{~g} / \mathrm{cm}^{3}\right)$ and a fresh water solution $\left(1.000 \mathrm{~g} / \mathrm{cm}^{3}\right)$; therefore the estimate of groundwater elevation can be calculated as being up to $8 \mathrm{~m}$ too low. In reality however, the final fluid sampled likely provided reasonable estimates for final equivalent freshwater head levels, as the salinity decrease was slowing in later samples. This provided equivalent freshwater head levels of 88 mbgs, or 252 m ASL.

\section{Hydraulic Conductivity}

While inspection of the core reveals several fractures beneath the permafrost that appear to be conduits for fluid flow, the lack of detailed data on conductive features and their distribution prevent development of a rigorous conceptual hydrologic model for fracture flow. It is instructive however to estimate an equivalent porous media hydraulic conductivity. Hydraulic conductivity estimates for the borehole were calculated using Jacob's logarithmic approximation from pressures recorded at the inlet to the U-tube sampling system as the reservoir in the BHA filled with fluid (Cooper and Jacob 1946; de Marsily 1986; Freifeld et al., 2008b). The hydraulic conductivity was estimated to be $7.0 \times 10^{-12} \mathrm{~m} / \mathrm{s}$, assuming a reservoir thickness equivalent to the length of the open borehole $(70 \mathrm{~m})$. While Jacob's equation imposes boundary conditions and assumptions that are applicable to a continuous confined porous medium, without specific information on actual fracture flow, the hydraulic conductivity estimated is indicative of unfractured crystalline rocks (e.g., Mazurek 2000; Stober and Bucher 2007).

\section{Discussion}

\section{Evaluation of U-Tube Fluid Samples}

Uranine and tritium concentrations were used to determine the relative mixtures of natural and drill fluids in the purged water samples collected from the U-tube. Tritium is a commonly used natural tracer present in modern meteoric water, and would be found at similar activity levels in both 2006 and 2007 drilling fluids. Uranine was added to the 2007 drill fluid to differentiate between the 2006 and 2007 drill fluids (Table 2). The observed uranine dilution in the first purge sample indicated drill fluid had mixed with fluid already in the borehole, either formation water or fluid from the 2006 drilling campaign (Table 2). The tritium activity in the purged samples indicated that fluids introduced to the borehole during drilling had mixed with older water. The tritium activity also predicted a slightly larger component of surface drill fluids in the purged samples compared to the estimate derived using uranine concentrations (Table 2). U-tube purges 4, 6, and 7, therefore, represented mixtures of drill water and $50 \%$ or more natural water, with purges 6 and 7 containing the highest percentage of natural water, although in total only $\sim 20 \%$ of the fluid beneath the packer was removed during U-tube sampling. 

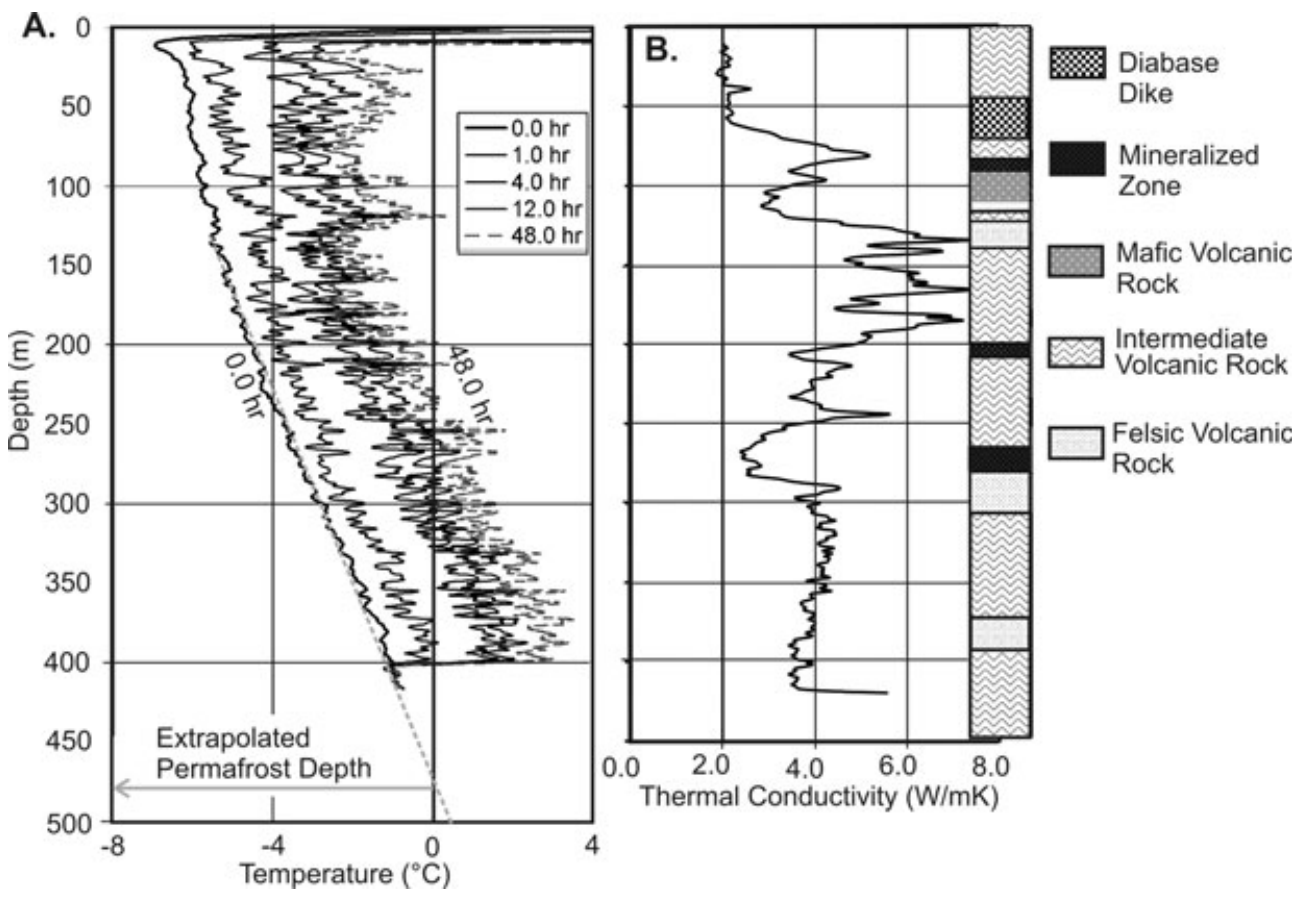

Figure 6. High Lake thermal profiles acquired using a distributed temperature sensor. Heating was initially conducted at a rate of $16.8 \mathrm{~W} / \mathrm{m}$ for $43 \mathrm{~h}$ followed by heating at $20.5 \mathrm{~W} / \mathrm{m}$ for $21 \mathrm{~h}$. Following the geothermal gradient, the thermal profiles go from coolest (shallowest) to warmest (deepest). (A) Profiles with depth plotted at specific times. The $0.0 \mathrm{~h}$ was determined after the borehole remained unperturbed for a period of one month. The gray dashed line indicates the trend extrapolated to calculate permafrost depth. (B) Thermal conductivity as a function of depth using a one-dimensional model to invert DTS data (from Freifeld et al. 2008a).

The stable isotopic compositions of the final U-tube samples were lower than drill fluid and surface water samples, also indicating a significant influx of natural fluid. Although precipitation stable isotope data are not available for the High Lake area, most surface samples plotted in a small area on the $\delta^{18} \mathrm{O}-\delta^{2} \mathrm{H}$ plot, appeared unaffected by evaporation, and are likely representative of mean annual precipitation (Figure 3A). The first U-tube sample (" 1 " in Figure 3A) had a stable isotopic composition similar to the drill fluid, surface water in the High Lake area and water bailed from the borehole after drilling in 2006 (Pfiffner et al. 2008). However, during subsequent purges, isotopic values decreased, and were similar to isotopic values sampled in the subpermafrost (570 to 1300 mbgs) at the Lupin Au Mine (Figure 3B) (Stotler et al. 2009). This correlation will be discussed later in the paper.

The speed at which the borehole purged the contaminated drill water was surprising, given the small proportion of fluid removed during U-tube sampling. As the sampling point was not beneath the base of the permafrost, it is possible that the warm, briny, drill water may have melted some permafrost ice beneath the casing. The dense drilling brine may have also displaced resident fresh water at the bottom of the borehole, resulting in density driven mixing. Further, an unknown quantity of drill fluid was removed during the drill string "wet pull." Regardless, the trends observed in chemical and isotopic tracers over successive sampling events indicated later U-tube samples had less influence from drill fluids and thus were more representative of natural fluid (Table 2).

\section{Subpermafrost Hydrology}

\section{Hydraulic Head}

Regardless of the uncertainties associated with groundwater elevations at the site, these results clearly indicated the piezometric surface (252 $\mathrm{m} \mathrm{ASL}$ ) at the site was well above the base of permafrost $(\sim 78 \mathrm{~m}$ below sea level), and within $100 \mathrm{~m}$ of the borehole collar $(368 \mathrm{~m}$ ASL). The large relief in the study area also meant this piezometric surface was between the surface elevation of High Lake (283.3 m ASL), and the Kennarctic River ( $200 \mathrm{~m} \mathrm{ASL}$ ), indicating neither low, nor excess, pressures occurred beneath the permafrost. Significantly, this also demonstrated that an unsaturated zone beneath permafrost ("dry permafrost") was not present at High Lake, and suggested the suspected unsaturated zone at the base of permafrost at the Lupin Au Mine was a result of mining operations, as hypothesized. With only one data point, a hydraulic connection through open taliks beneath High Lake and the Kennarctic River could not be established, but also could not be dismissed.

\section{Fluid Chemistry}

Despite the contamination of drilling brine in the U-tube samples, some determinations about the 


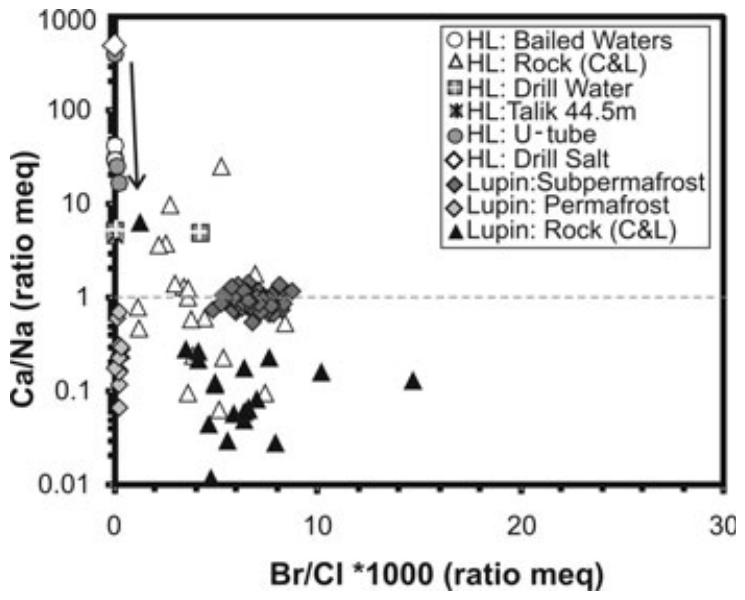

Figure 7. $\mathrm{Ca}^{2+}: \mathrm{Na}^{+}$vs. $\mathrm{Br}^{-}: \mathrm{Cl}^{-}$plot for High Lake water samples, with Lupin mine samples for comparison. Drill water samples were collected prior to addition of salt. The arrow shows the direction of successive samplings in the U-tube sampler. Fluid data are plotted meq/L, salt and crush and leach data are plotted meq/kg. Lupin data are from Stotler et al. (2009).

basal/subpermafrost fluid at High Lake are possible. Matrix fluids and U-tube sampled groundwater did not have similar $\mathrm{Ca} / \mathrm{Na}$ ratios or $\mathrm{Br} / \mathrm{Cl}$ ratios (Figure 7). Matrix fluids were generally $\mathrm{Na}$ dominant, although several were $\mathrm{Ca}$ dominant (Figure 7). Although U-tube samples were Ca-rich, matrix fluids were generally $\mathrm{Na}$-rich. The final U-tube samples had much lower $\mathrm{Ca} / \mathrm{Na}$ ratios than initial samples, resulting from a reduced proportion of the $\mathrm{Ca}-\mathrm{Cl}$ drilling brine, and were similar to High Lake surface and talik water, (Table 1). As the U-tube $\mathrm{Ca} / \mathrm{Na}$ ratio decreased with time, it trended toward the matrix fluid $\mathrm{Ca}$-dominant end-member $\mathrm{Ca} / \mathrm{Na}$ ratios, although the final groundwater ratios were still higher. $\mathrm{Br} / \mathrm{Cl}$ ratios also remained in disequilibrium. Thus, it is suggested that the natural basal-subpermafrost fluids at High Lake were slightly $\mathrm{Ca}$ dominant, with salinity less than $20,000 \mathrm{mg} / \mathrm{L}$.

High Lake U-tube samples exhibited similar, low, stable isotope values $\left(\delta^{2} \mathrm{H} \delta^{18} \mathrm{O}\right)$ as those found in deep-permafrost and subpermafrost water sampled at the Lupin Au Mine (Figure 3B). This correlation may indicate fractionation during ice formation, due to permafrost formation, is the dominant process affecting fluid stable isotopic values at these sites. Stable isotopes are known to fractionate during ice formation, and depleted $\delta^{2} \mathrm{H}$ and $\delta^{18} \mathrm{O}$ values in fluids are expected as a result of in situ ice formation (Craig and Hom 1968; O'Neil 1968; Souchez and Jouzel 1984; Stotler et al. 2009; Suzuoki and Kimura 1973). The values could represent a fluid isotopic end-member resulting from permafrost formation in this portion of the Canadian Shield. With only two sites investigated to date, additional study is still required to definitively determine whether the observed isotopic values are the result of isotopic fractionation due to ice formation during permafrost formation or some other unknown process.

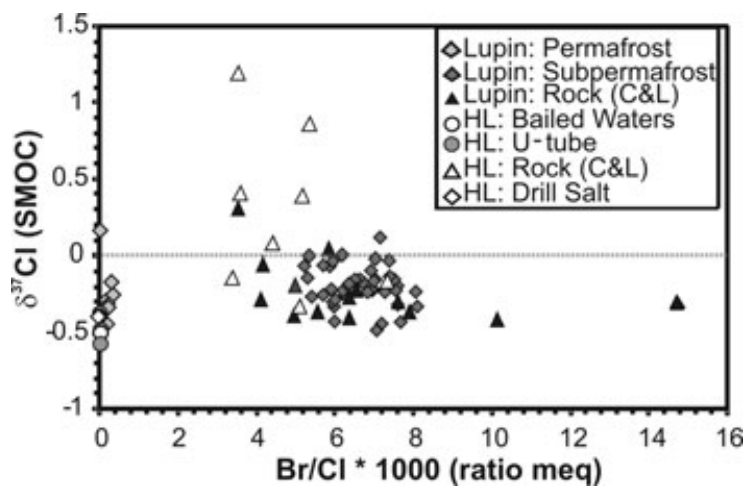

Figure 8. Chlorine stable isotopic composition vs. $\mathrm{Cl}^{-}$concentration of High Lake samples, compared with samples from the Lupin mine. Lupin data are from Stotler et al. (2009).

Additional insight into the origin of $\mathrm{Cl}^{-}$in High Lake fluids was provided through analysis of the stable chlorine isotopic compositions of U-tube, matrix fluids (obtained using crush and leach), and drill salt. Bailed water (from 2006) and U-tube samples had similar $\delta^{37} \mathrm{Cl}$ values as the salt used to form the drilling brine $(\sim-0.4 \%$ o SMOC), which was lower than $\delta^{37} \mathrm{Cl}$ values in most matrix fluids $(-0.3 \%$ o to $0.9 \%$ o SMOC) (Figure 8). This indicates that $\mathrm{Cl}^{-}$in the basal/subpermafrost fluids was not in equilibrium with matrix fluid $\mathrm{Cl}^{-}$, and confirms the conclusion that a majority of the $\mathrm{Cl}^{-}$sampled by the U-tube was contaminated by the drilling fluids. High Lake matrix fluid $\delta^{37} \mathrm{Cl}$ values had a larger range, and were generally more enriched than either the Lupin Au Mine matrix fluids (also obtained by crush and leach methods) or Canadian Shield brines (e.g., Frape et al. 2004; Stotler 2008; Stotler et al. 2009, 2010a) (Figure 8). The process causing the isotopic enrichment and larger range of $\delta^{37} \mathrm{Cl}$ at High Lake is currently unknown. At other sites within the Canadian Shield, variations in rock $\delta^{37} \mathrm{Cl}$ have been observed in hydrothermal alteration haloes (Hanley and Mungall 2003). The large range of $\delta^{37} \mathrm{Cl}$ values observed at High Lake may also be attributed to changes in geologic setting or hydrothermal alteration with depth through the borehole; however, additional study of rock $\delta^{37} \mathrm{Cl}$ values would be required.

Fresh to saline fluids have been observed in the crystalline basal permafrost/subpermafrost environment. The chemical and isotopic characteristics of basal permafrost and subpermafrost fluids investigated at High Lake and the Lupin Au Mine are distinct from, and do not indicate a common evolutionary pathway to the ${ }^{2} \mathrm{H}$-enriched, Ca-rich brines (with salinities over $300 \mathrm{~g} / \mathrm{L}$ ) found at sites across the Canadian Shield (e.g., Frape et al. 2004). These data indicate that the freeze-out process is a distinct evolutionary process not related to Canadian Shield Ca-rich brine formation.

\section{Biogeochemistry}

Insufficient DNA was present in the core samples for successful amplification and sequencing, so inference 
drawn regarding the biogeochemistry of the permafrost system is based upon the geochemistry of the matrix fluid, the gas analyses, thermodynamic calculations and measurements of the ${ }^{35} \mathrm{SO}_{4}{ }^{2-}$ reduction activity of the cores.

The $\mathrm{C} 1 /(\mathrm{C} 2+\mathrm{C} 3)$ in both samples (Table 3$)$ is not typical of methanogenic $\mathrm{CH}_{4}$ (e.g., Whiticar et al. 1986). Investigations at the Lupin Au Mine suggested the possibility of $\mathrm{CH}_{4}$ hydrate formation within crystalline rock in the permafrost setting (Stotler 2008; Stotler et al. $2010 b$ ). This is potentially important to subpermafrost geochemistry, as $\mathrm{CH}_{4}$ hydrate formation and dissipation can affect gas chemical composition and fluid chemical and isotopic composition (Trofimuk et al. 1974; Hesse and Harrison 1981; Milkov et al. 2004). The subsurface temperature and pressure conditions at the U-tube sample depth were within the $\mathrm{CH}_{4}$ hydrate stability field, given the salinity of the matrix fluid (Elwood Madden et al. 2007). Owing to the lack of gas quantity data, it was not possible to confirm the presence of $\mathrm{CH}_{4}$ hydrates. Negligible $\mathrm{O}_{2}$ amounts indicate the sampled gases were primarily naturally occurring, with only small inputs from drilling fluid and that the subpermafrost environment is at least hypoxic. The high $\mathrm{Ca}^{2+}$ and $<1 \mathrm{mM} \mathrm{HCO}_{3}{ }^{-}$ concentrations and the high $\mathrm{pH}$ values of 10 to 11 for the matrix fluid indicate that the matrix fluid is in equilibrium with calcite, as was the case at the Lupin Au Mine (Onstott et al. 2009). The $\mathrm{NO}_{3}{ }^{-}$concentrations were $<40 \mu \mathrm{M}$. The $\mathrm{mM} \mathrm{SO}_{4}{ }^{2-}$ concentrations, therefore, suggest that $\mathrm{SO}_{4}{ }^{2-}$ reduction is the principal electron acceptor. No $\mathrm{HS}^{-}$was detected in the pore fluid, which constrains the $\mathrm{HS}^{-}$concentration to be $<40 \mathrm{mM}$. For other deep fractured rock aquifers, the $\mathrm{HS}^{-}$and $\mathrm{Fe}^{2+}$ concentrations indicated that they were either undersaturated with respect to FeS (Hallbeck and Pedersen 2008) or close to saturation with respect to $\mathrm{FeS}$ (Onstott et al. 2006). Assuming equilibrium with $\mathrm{FeS}$, the $\mathrm{Fe}^{2+}$ concentrations therefore provide a maximum constraint on the $\mathrm{HS}^{-}$ concentrations of $0.01 \mu \mathrm{M}$. The $\Delta G$ for acetate and formate oxidizing $\mathrm{SO}_{4}{ }^{2-}$ reduction ranged from -128 to -156 and -239 to $284 \mathrm{~kJ}\left(\mathrm{~mol} \mathrm{SO}_{4}{ }^{2-}\right)^{-1}$, respectively, and represent minimum estimates of the free energy. The high acetate concentrations, relative to the $\mathrm{SO}_{4}{ }^{2-}$ concentrations (Table 4), suggest that the acetate oxidizing SRB's (sulfate reducing bacteria) are electron acceptor limited. The $\mathrm{SO}_{4}{ }^{2-}$ concentrations of the pore water is $\sim 10$ times greater than that of the U-tube samples and surface water, which suggests that the $\mathrm{SO}_{4}$ originated from the mineral matrix and is diffusing into the subpermafrost water along with the organic acids. The increase in the $\mathrm{SO}_{4}{ }^{2-}$ reduction rate with depth (Figure 5) is correlated with increasing acetate and formate concentrations and with increasingly more negative $\Delta G$ values. The $10^{-4}$ to $10^{-1} \mathrm{nmol} / \mathrm{cm}^{3} /$ day rates for $\mathrm{SO}_{4}{ }^{2-}$ reduction overlap with those reported by Kallmeyer (2003) for subseafloor sediments from the Peruvian margin where the $\mathrm{SO}_{4}{ }^{2-}$ concentrations are comparable to those reported here. Without any constraint on the cellular concentrations in these rock cores, however, it is impossible to compare cellular rates.

Assuming that $\mathrm{CH}_{4}$ hydrate formation constrains the $\mathrm{pCH}_{4}$ to 100 bars, the $\Delta G$ values for acetate and formate methanogenic reactions range from -41 to -51 and -153 to $-171 \mathrm{~kJ}\left(\mathrm{~mol} \mathrm{CH}_{4}\right)^{-1}$, respectively. These values are less than the corresponding acetate and formate oxidizing SRB reactions, which suggest that the SRB's would outcompete methanogens in this environment. This would be consistent with the observation that the C1-3 gas composition is not methanogenic.

\section{Evaluation of Surface Investigation of Permafrost Approach}

This investigation sampled natural deep-permafrost water from a surface-drilled borehole at an undisturbed location. Both advantages and disadvantages of this approach were realized when compared with the underground investigations conducted at the Lupin Au Mine (Ruskeeniemi et al. 2002, 2004; Stotler 2008; Stotler et al. 2009, 2010b; Onstott et al. 2009). The underground approach provided high quality chemistry data below $800 \mathrm{~m}$, but gases and hydraulic head measurements were susceptible to depressurization resulting from mine drawdown, which also affected estimates of undisturbed freshwater head. On the other hand, the surface borehole BHA approach demonstrated in this study provided high quality physical information. Significant contamination of the samples (37\% to $100 \%$ drill fluid) was observed, but useful information about natural chemical conditions near the base of the permafrost was also obtained. The surface approach was expensive compared with sampling in an available mine, the borehole froze too rapidly for application of standard surface sampling methods, and the down-hole sampling apparatus needed to be installed within $5 \mathrm{~h}$ of drill string removal. However, extra effort often must be applied to unraveling mine related effects from natural conditions (e.g., Stotler et al. 2009). On the balance, the surface-drilled borehole provided high quality physical and chemical information about the subsurface, with fewer potential contaminants that were both controlled and known.

With the experience gained from this investigation, several suggestions are provided for future surface boreholes investigations of the basal permafrost and subpermafrost environment. Our results indicate drill salt contamination remains an issue when extending boreholes previously drilled with brine, but given isolation with a packer, sample quality will improve with time. Many study locations in the arctic are associated with mine exploration, and existing boreholes are drilled through or toward metallic, high thermal conductivity ore zones. Inspection of the temperature data collected during the in situ heating experiment indicated that during heating with the heat tracer tape, temperatures increased to nearly freezing throughout the entire borehole. We conclude that thermal insulation in the form of a small insulating jacket around the heat trace and U-tube sampling lines 
should allow temperatures to rise above freezing, and prevent freezing within the sample tubes during sample retrieval. This would permit sampling through high thermal conductivity zones. If drilling with heated fresh water rather than brines, drilling should proceed more slowly, providing the rock surrounding the borehole adequate opportunity to warm up and allow a maximum time for installation of a BHA. We recommend that when recirculation of drill fluids is halted, the fluid remaining in the borehole should have a target temperature of $60^{\circ} \mathrm{C}$, as water near boiling (i.e., $90{ }^{\circ} \mathrm{C}$ ) may freeze more quickly than cooler water $\left(40{ }^{\circ} \mathrm{C}\right.$ to $\left.60{ }^{\circ} \mathrm{C}\right)$. In instances where ambient temperatures range from $-5{ }^{\circ} \mathrm{C}$ to $-11{ }^{\circ} \mathrm{C}$, hot water has been shown to freeze faster than cold water in a process known as the Mpemba Effect (Jeng 2006). When installing a BHA, the sampling lines and heat tape should be wrapped with insulation to help prevent freezing, heat tape should be installed with a safety factor (i.e., if the highest thermal conductivity expected is $4 \mathrm{~W} / \mathrm{mK}$, plan for $10 \mathrm{~W} / \mathrm{mK}$ ), and extra attention should be paid to warming the "cold trap" portion of the permafrost. Future BHA should contain an injection tube that can be used to inject sterile chemical tracers or microbial nutrients, both aqueous and gaseous, into the subpermafrost zone to measure in situ flow and metabolic rates that can be compared to those derived from measurements of the core samples as described earlier. A gas sampling and analysis system like those that have been used with previous U-tube experiments (Freifeld and Trautz 2006) should also be included.

Additional recommendations for future attempts to investigate groundwater in the basal/subpermafrost zone were developed as a result of this investigation. If the drill string has to be removed at any point prior to completion of the hole (e.g., for bit change), it is likely that the fluid in the borehole will cool down and start to freeze, and the drill string may freeze in the hole even after the drill string is returned to the borehole. The dilute drill water will then have to be replaced with brine, but once downward progress has resumed, drill fluid can be diluted again. If the drilled borehole is productive, and the technical instrumentation allows flushing or pumping through the permafrost, contamination with drilling brine can be overcome. However the coldest portions of the borehole will act as a "cold trap," drawing moisture to this point, which will subsequently freeze. When drilling a hole for such research the borehole instrumentation should be located on site and ready for immediate installation once drilling is complete. Any down-hole soundings or tests, for example, to locate flow points, are hazardous due to the freezing risk and should be undertaken only if the thermal conditions within the borehole allow. If contamination is not an issue, brine could be circulated during testing. For more accurate borehole pressure measurements, in situ EC should be measured, given the possibility that it may not be possible to determine EC from the surface. The recommendations listed for future investigations should aid in minimizing the contamination of samples with drilling brine and maximize the scientific benefit of the borehole.

\section{Conclusions}

This study illustrated that drill brine contamination in permafrost remains a major restriction for investigation of the influence of permafrost formation and ice formation on groundwater chemistry. This approach improved time available for sample collection considerably over past approaches, and provided the opportunity for collection of multiple samples. The U-tube geochemical sampling approach presented in this paper demonstrated the difficulty of obtaining high quality geochemical samples, and possibilities for overcoming remaining challenges. Additional guidelines and recommendations, a result of the experiences of this investigation, were provided for consideration of future investigations of deep-permafrost/subpermafrost fluids.

Surface and shallow talik water in the High Lake area were fresh. HLW-03-28 matrix fluid $\delta^{37} \mathrm{Cl}$ values at High Lake were more enriched than measured at the Lupin Au Mine, with a greater range, likely a result of metamorphic processes. ${ }^{35} \mathrm{SO}_{4}{ }^{2-}$ reduction rates, geochemical analyses and thermodynamic calculations suggest that $\mathrm{SO}_{4}{ }^{2-}$ reduction is the dominant microbial process similar to the subpermafrost environment at the Lupin $\mathrm{Au}$ Mine. This is consistent with the $\mathrm{C} 1 /(\mathrm{C} 2+\mathrm{C} 3)$ values of trace amounts of $\mathrm{CH}_{4}$ and higher hydrocarbons measured from the U-tube samples even though the isotopic composition of the $\mathrm{CH}_{4}$ was not determined. Tracer analysis (uranine and tritium) of U-tube samples suggested that contamination of drill brine decreased significantly over a relatively brief time. Chemical and isotopic analysis of the U-tube samples also indicated mixtures of drill fluid and formation water. However, stable isotopic values $\left(\delta^{2} \mathrm{H}, \delta^{18} \mathrm{O}\right)$ in this borehole were similar to isotopic values sampled in deep-permafrost/subpermafrost fluid at the Lupin Au Mine. It is suggested that these values are a result of ice formation within the permafrost. Trace amounts of methane and higher hydrocarbons were also found in the U-tube samples; the ratio of methane to ethane and propane suggested that the gases were not likely bacteriogenic, although isotopic composition was not determined to identify the specific gas origin. The sampling interval was located within the hydrate stability field, although it was not possible to determine whether the $\mathrm{CH}_{4}$ concentrations were consistent with $\mathrm{CH}_{4}$ hydrate formation.

Despite drill fluid contamination, several of the research objectives were achieved. The fluid sampled at the base of the permafrost had a $\mathrm{Ca} / \mathrm{Na}$ ratio of $\sim 10$. Although these samples were contaminated, the trends observed during sampling indicated natural fluids had salinities less than $20,000 \mathrm{mg} / \mathrm{L}$, with a $\mathrm{Ca} / \mathrm{Na}$ ratio $\leq 10$. Stable isotopic values $\left(\delta^{2} \mathrm{H}, \delta^{18} \mathrm{O}\right)$ indicated that groundwater was affected by ice formation resulting from development of permafrost. Thus in situ freeze-out due to permafrost formation did not create calcium brine at this site. In an undisturbed system, it was possible to determine hydraulic head values. Basal permafrost hydraulic heads were well above the base of the permafrost, near land surface, indicating the "dry permafrost" observed at the Lupin Au Mine was an artifact of mine dewatering. With 
only one data point, it was not possible to determine a connection through open taliks to surface water bodies, but such a connection could also not be dismissed.

\section{Acknowledgments}

Funding for the project was provided by the Geological Survey of Finland, POSIVA Oy, Finland, SKB, Sweden, Nuclear Waste Management Organization, Ontario, Canada, and a grant from the NASA Astrobiology Institute (NASA NNA04CC03A). Wolfden Resources, Inc. and Zinifex Inc. provided site access. Norm Case and Discovery Mining provided logistical support. Ian Neill and Trish Toole provided logistical and managerial support while at the site. Field support was also provided by Bob Ingleton, Adam Johnson, Eric Chan, Dan McGown, and Sarah Difurio. John Tellam and two anonymous reviewers provided constructive and insightful reviews that improved the manuscript.

\section{References}

Alexeev, S.V., and L.P. Alexeeva. 2002. Ground ice in the sedimentary rocks and kimberlites of Yakutia, Russia. Permafrost and Periglacial Processes 13, no. 1: 53-59.

Alexeev, S.V., and L.P. Alexeeva. 2003. Hydrogeochemistry of the permafrost zone in the central part of the Yakutian diamond-bearing province, Russia. Hydrogeology Journal 11, no. 5: 574-581.

Burn, C.R. 2002. Tundra lakes and permafrost, Richards Island, western Arctic coast, Canada. Canadian Journal of Earth Science 39, no. 8: 1281-1298.

Cameron, E.M., and S.B. Ballantyne. 1975. Experimental hydrogeochemical surveys of the High Lake and Hackett River Areas, Northwest Territories. Geological Survey of Canada Paper 15: 75-29.

Cooper, H.H., and C.E. Jacob. 1946. A generalized graphical method for evaluating formation constants and summarizing well field history. Transactions-Americal Geophysical Union 27, no. 4: 526-534.

Cord-Ruwisch, R. 1985. A quick method for the determination of dissolved and precipitated sulfides in cultures of sulfatereducing bacteria. Journal of Microbiological Methods 4, no. 1: $33-36$.

Craig, H., and B. Hom. 1968. Relationships of deuterium, oxygen-18, and chlorinity in the formation of sea ice. Transactions-Americal Geophysical Union 49, no. 1: $216-217$.

Cumberland Resources, Ltd. 2005. Meadowbank gold project, Baseline Physical Ecosystem Report 68.

Dallimore, S.R., T. Uchida, and T.S. Collett (Eds.). 1999. Scientific results from JAPEX/JNOC/GSC Mallik 2L-38 Gas Hydrate Research Well, Mackenzie Delta, Northwest Territories, Canada. Geological Survey of Canada Bulletin 544, 403.

Dallimore, S.R., and T.S. Collett (Eds.). 2005. Scientific results from the Mallik 2002 Gas Hydrate Production Research Well Program, Mackenzie Delta, Northwest Territories, Canada. Geological Survey of Canada Bulletin 585.

Eggenkamp, H.G.M. 1994. The geochemistry of chlorine isotopes. Ph.D. diss., Utrecht University, The Netherlands.

Elwood Madden, M., S. Ulrich, T.C. Onstott, and T.J. Phelps. 2007. Salinity-induced hydrate dissociation: a mechanism for recent methane release on Mars. Geophysical Research Letters 34, no. 11: L11202. DOI: 10.1029/2006GL029156.
Epstein, S., and T.K. Mayeda. 1953. Variation of the ${ }^{18} \mathrm{O}$ content of waters from natural sources. Geochimica et Cosmochimica Acta 4, no. 5: 213-224.

van Everdingen, R.O. 1976. Geocryological terminology. Canadian Journal of Earth Science 13, no. 6: 862-867.

Frape, S.K., A. Blyth, R. Blomqvist, R.H. McNutt, and M. Gascoyne. 2004. Deep fluids in the continents: II. Crystalline rocks. In Surface and Ground Water, Weathering, and Soils, ed. J.I. Drever, vol. 5: Treatise on Geochemistry, ed. H.D. Holland and K.K. Turekian, 541-580. Oxford: Elsevier-Pergamon.

Freifeld, B.M., R.C. Trautz, Y.K. Kharaka, T.J. Phelps, L.R. Myer, S.D. Hovorka, and D.J. Collins. 2005. The U-tube: a novel system for acquiring borehole fluid samples from a deep geologic $\mathrm{CO} 2$ sequestration experiment. Journal of Geophysical Research 110, no. B10: B10203. DOI: 10.1029/2005JB003735.

Freifeld, B.M., and R.C. Trautz 2006. Real-time quadrupole mass spectrometer analysis of gas in borehole fluid samples acquired using the U-tube sampling methodology. Geofluids 6, no. 3: 217-224.

Freifeld, B.M., S. Finsterle, T.C. Onstott, P. Toole, and L.M. Pratt. 2008a. Ground surface temperature reconstructions using in situ estimates for thermal conductivity acquired with a fiber-optic distributed thermal perturbation sensor. Geophysical Research Letters 35, no. 14: L14309.

Freifeld, B.M., E. Chan, T.C. Onstott, L.M. Pratt, A. Johnson, R. Stotler, B. Holden, S. Frape, S.M. Pfiffner, S. DiFurio, T. Ruskeeniemi, and I. Neill. 2008b. Deployment of a deep borehole observatory at the High Lake Project site, Nunavut, Canada. Ninth International Conference on Permafrost (ICOP) Proceedings, 469-474.

Freifeld, B.M. 2009. The U-tube: a new paradigm for borehole fluid sampling. Scientific Drilling 8: 41-45. DOI: 10.2204/iodp.sd.8.07.2009.

Gartner Lee Ltd. 2006a. High Lake Environmental Assessment, Appendix A: Hydrogeological Modelling of the Proposed High Lake Mine. Prepared for Wolfden Resources Inc., GLL 41-120.

Gartner Lee Ltd. 2006b. Field Report, High Lake Project, Hydrogeology. Prepared for Wolfden Resources Inc., GLL 61-014.

Gartner Lee Ltd. 2006c. Draft Field Report-High Lake Project Surface Water Hydrology. 2004 \& 2005. Prepared for Wolfden Resources Inc., GLL 51009.

Gartner Lee Ltd. 2006d. Field Report High Lake Project Water and Sediment Quality-2004-2005. Prepared for Wolfden Resources Inc., GLL 51009.

Gaucher, E.C., P. Blanc, F. Bardot, G. Braibant, S. Buschaert, C. Crouzet, A. Gautier, J.-P. Girard, E. Jacquot, A. Lassin, G. Negrel, C. Tournassat, A. Vinsot, and S. Altmann, 2006. Modelling the porewater chemistry of the CollovianOxfordian formation at a regional scale. Comptes Rendus Geosciences 338, no. 12-13: 917-930.

Hallbeck, L., and K. Pedersen. 2008. Characterization of microbial processes in deep aquifers of the Fennoscandian Shield. Applied Geochemistry 23: 1796-1819.

Hanley, J.J., and J.E. Mungall. 2003. Chlorine enrichment and hydrous alteration of the Sudbury Breccia hosting footwall $\mathrm{Cu}-\mathrm{Ni}$-PGE mineralization at the Fraser Mine, Sudbury, Ontario. Canada. The Canadian Mineralogist 41, no. 4: $857-881$.

Hesse, R., and W.E. Harrison. 1981. Gas hydrates (clathrates) causing pore-water freshening and oxygen-isotope fractionation in deep-water sedimentary sections of terrigenous continental margins. Earth and Planetary Science Letters 55, no. 3: 453-462.

Jeng, M. 2006. Hot water can freeze faster than cold? American Journal of Physics 74, no. 6: 514-522.

Jorgenson, M.T., Y.L. Shur, and E.R. Pullman. 2006. Abrupt increase in permafrost degradation in Arctic Alaska. 
Geophysical Research Letters 33, no. 2: L02503. DOI: 10.1029/2005GL024960.

Kallmeyer J., T.G. Ferdeoman, A. Weber, H. Fossing, and B.B. Jorgensen. 2004. A cold chromium distillation procedure for radiolabeled sulfide applied to sulfate reduction measurements. Limnology and Oceanography: Methods 2, no. 6: $171-180$.

Kleinberg, R.L., C. Flaum, D.D. Griffen, P.G. Brewer, G.E. Malby, E.T. Peltzer, and J.P. Yesinowski. 2003. Deep sea NMR: Methane hydrate growth habit in porous media and its relationship to hydraulic permeability, deposit accumulation, and submarine slope stability. Journal of Geophysical Research 108, no. B10: 2508. DOI: 10,1029/2003JB002389.

Krumholz, L.R., J.P. McKinley, G.A. Ulrich, and J.M. Suflita. 1997. Confined subsurface microbial communities in Cretaceous rock. Nature 386, no. 6620: 64-66.

Kvenvolden, K.A., and T.D. Lorenson, 2001. The global occurrence of natural gas hydrate. In Natural Gas Hydrates: Occurrence, Distribution, and Dynamics, AGU Monograph Series, vol. 124, ed. C.K. Paull, and W.P. Dillon, 3-18.

Mackay, J.R. 1992. Lake stability in an ice-rich permafrost environment: examples from the western Arctic coast, In Aquatic Ecosystems in Semi-arid Regions: Implications for Resource Management, Symposium Series, vol. 7, ed. R.D. Robarts and M.L. Bothwell, 1-26. Saskatoon: National Hydrology Research Institute, Environment Canada.

de Marsily, G. 1986. Quantitative Hydrogeology. Montreal: Academic Press, Inc.

Mazurek, M. 2000. Geological and hydraulic properties of waterconducting features in crystalline rocks. In Hydrogeology of Crystalline Rocks, vol. 34, ed. I Stober and K. Bucher, 3-26. Kluwer Academic Publishers, Water Science and Technology Library, Dordrecht, The Netherlands.

Milkov, A.V., G.E. Claypool, Y.-J. Lee, M.E. Torres, W.S. Borowski, H. Tomaru, R. Sassen, P.E. Long, and ODP Leg 204 Scientific Party. 2004. Ethane enrichment and propane depletion in subsurface gases indicate gas hydrate occurrence in marine sediments at southern Hydrate Ridge, offshore Oregon. Organic Geochemistry 35, no. 9: 1067-1080.

Morrison, J.T., T. Brockwell, T. Merren, F. Fourel, and A.M. Phillips. 2001. On-line high-precision stable hydrogen isotopic analyses on nanoliter water samples. Analytical Chemistry 73, no. 15: 3570-3575.

Moser, H. (ed.) 1977. Jahresbericht 1977. Internal report of the Institute fur radiohydrometrie GSF Munich, vol. 169, $70-71$.

Natural Resources Canada. 1995. Canada-Permafrost. The National Atlas of Canada, 5th ed. MCR 4177F. http://atlas. nrcan.gc.ca/site/english/maps/archives/5thedition.

Norton, D., and R. Knapp. 1977. Transport phenomena in hydrothermal system: the nature of porosity. American. Journal of Science 277, no. 8: 913-936.

O’Neil, J.R. 1968. Hydrogen and oxygen isotope fractionation between ice and water. The Journal of Physical Chemistry 72, no. 10: 3683-3684.

Onstott, T.C., D.J. McGown, C. Bakermans, T. Ruskeeniemi, L. Ahonen, J. Telling, B. Soffientino, S.M. Pfiffner, B. Sherwood Lollar, S.K. Frape, R.L. Stotler, E.J. Johnson, T.A. Vishnivetskaya, R. Rothmel, and L.M. Pratt. 2009. Microbial communities in subpermafrost saline fracture water at the Lupin Au Mine, Nunavut, Canada. Microbial Ecology 58, no. 4: 786-807. DOI: 10.1007/s00248-0099553-5.

Petch, C.A. 2004. The geology and mineralization of the high lake volcanic-hosted massive sulfide deposit, Nunavut. Exploration Mining Geology 13, no. 1-4: 27-47.

Pfiffner, S., T.C. Onstott, T. Ruskeeniemi, M. Talikka, C. Bakermans, D. McGown, E. Chan, A. Johnson,
T. Phelps, M. LePuil, S., DiFurio, L. Pratt, R. Stotler, J. Telling, B. Sherwood Lollar, I. Niell, and B. Zerbin. 2008. Challenges for Coring Deep Permafrost on Earth and Mars. Astrobiology 8, no. 3: 1-57.

Ruskeeniemi, T., M. Paananen, L. Ahonen, J. Kaija, A. Kuivamäki, S. Frape, L. Moren, P. Degnan. 2002. Permafrost at Lupin: Report of Phase 1. Geological Survey of Finland, YST-112. 59 p. +3 app.

Ruskeeniemi, T., L. Ahonen, M. Paananen, S. Frape, R. Stotler, M. Hobbs, J. Kaija, P. Degnan, R. Blomqvist, M. Jensen, K. Lehto, L. Moren, I. Puigdomenech, and M. Snellman. 2004. Permafrost at Lupin: Report of Phase II. Geological Survey of Finland, Nuclear Waste Disposal Research. Report YST-119, 89

Selker, J.S., L. Thévenaz, H. Huwald, A. Mallet, W., Luxemburg, N. van de Giesen, M. Stejskal, J. Zeman, M. Westhoff, and M.B. Parlange. 2006. Distributed fiberoptic temperature sensing for hydrologic systems. Water Resources Research 42, no. 12: W12202. DOI: 10.1029/ 2006 WR005326.

Shouakar-Stash, O., R.J. Drimmie, J. Morrison, S.K. Frape, A.R. Heemskerk, and W.A. Mark. 2000. On-line D/H analysis for water, natural gas, and organic solvents by manganese reduction. Analytical Chemistry 72: no. 11: 2664-2666.

Shouakar-Stash, O., S.V. Alexeev, S.K. Frape, L.P. Alexeeva, and R.J. Drimmie. 2007. Geochemistry and stable isotopic signatures, including chlorine and bromine isotopes, of the deep groundwaters of the Siberian Platform, Russia. Applied Geochemistry 22, no. 3: 589-605.

Smellie, J.A.T., H.N. Waber, and S.K. Frape. 2003. Matrix fluid chemistry experiment, Final Report, June 1998-March 2003. SKB Technical Report TR-03-18, 162.

Souchez, R.A., and J. Jouzel. 1984. On the isotopic composition in delta D and delta (super 18)O of water and ice during freezing. Journal of Glaciology 30: 369-372.

SRK Consulting. 2005. Groundwater Assessment, Doris North Project, Hope Bay, Nunavut, Canada. Prepared for Miramar Hope Bay Limited. Project No. 1CM014.006.

Stober, I., and K. Bucher. 2007. Hydraulic properties of crystalline basement. Hydrogeology Journal 15, no. 2: 213-224.

Stotler, R.L. 2008. Evolution of Canadian shield groundwaters and gases: influence of deep permafrost. PhD Dissertation, Department of Earth Sciences, University of Waterloo, Waterloo, Ontario, Canada.

Stotler, R.L., S.K. Frape, T. Ruskeeniemi, L. Ahonen, T.C. Onstott, and M.Y. Hobbs. 2009. Hydrogeochemistry of groundwaters in and below the base of thick permafrost at Lupin, Nunavut, Canada. Journal of Hydrology 373: 80-95.

Stotler, R.L., S.K. Frape, and O. Shouakar-Stash. 2010a. An isotopic survey of $\delta^{81} \mathrm{Br}$ and $\delta^{37} \mathrm{Cl}$ of dissolved halides in the Canadian and Fennoscandian shields. Chemical Geology. DOI: 10.1016/j.chemgeo.2010.03.014.

Stotler, R.L., S.K. Frape, L. Ahonen, I.D. Clark, S. Greene, M. Hobbs, E. Johnson, J.-M. Lemieux, W.R. Peltier, L. Pratt, T. Ruskeeniemi, E.A. Sudicky, and L. Tarasov. 2010b. Thermogenic Methane Hydrate in a Crystalline Shield. Earth and Planetary Science Letters.

Streltsova, T.D. 1988. Well Testing in Heterogeneous Formations. New York: John Wiley \& Sons, 413.

Suzuoki, T., and T. Kimura. 1973. D/H and 18O/16O fractionation in ice-water system. Mass Spectroscopy 21, no. 3: $229-233$.

Taylor, C.B. 1977. Tritium enrichment of environmental waters by electrolysis: development of cathodes exhibiting high isotopic separation and precise measurement of 
tritium enrichment factors. Proceedings of the International Conference of Low-Radioactivity Measurements and Applications. Bratislava: Slovenski Pedagogicke Nakladatelstvo, $131-140$.

Tolstikhin, N.I., and O.N. Tolstikhin. 1974. Groundwater and surface water in the permafrost region. In General Permafrost Studies, ed. P.I. Melnikov, and O.N. Tolstikhin, 25. Ottawa: USSR Academy of Sciences, Novosibirsk, English translation, Environment Canada, Inland Waters Directorate, Technical Bulletin No. 97 (translation published in 1976).

Trofimuk, A.A., N.V. Cherskiy, and V.P. Tsarev. 1974. Mechanism of fractionation of isotopes of water and gas in crustal zones of hydrate formation. Doklady Akademii Nauk SSSR 215, no. 5: $1226-1229$.
Vidstrand, P. 2008. Numerical studies of permafrost effect on groundwater flow. International Conference on Permafrost (ICOP) Proceedings 9: 1833-1838.

Waber, H.N., and J.A.T. Smellie. 2008. Characterisation of pore water in crystalline rocks. Applied Geochemistry 23, no. 7: 1834-1861. DOI: 10.1016/j.apgeochem.2008.02.007.

Waber, H.N., and S.K. Frape. 2002. Djupförvarsteknik matrix fluid chemistry experiment. Synthesis Report: Drillcore pore water leaching studies and borehole water. SKB Technical Document TD-03-02, 67.

Whiticar, M.J., E. Faber, and M. Schoell. 1986. Biogenic methane formation in marine and freshwater environments: $\mathrm{CO}_{2}$ reduction vs. acetate fermentation-isotope evidence. Geochimica et Cosmochimica Acta 50, no. 5: 693-709. 